УДК $347.77 / 78$

\author{
О. І.. Харитонова, Г. О.Ульянова, А.В. Кирилюк, \\ Ю. Ю. Симонян, Н. П. Бааджи, Д. Д. Позова, \\ Г. І̇. Григор'яни, Л. І̇. Бурова, Ї. В. Мартинюк
}

\title{
ПРОБЛЕМНІ ПИТАННЯ ВИЗНАЧЕННЯ ПРАВОВОЇ ПРИРОДИ І СТРУКТУРИ ПРАВОВїДНОСИН ІНТЕЛЕКТУАЛЬНОЇ ВЛАСНОСТІ, ЩО ВИНИКАЮТЬ У МЕРЕЖІ ЇНТЕРНЕТ
}

Технічний прогрес, в основі якого беззаперечно $є$ результати інтелектуальної діяльності, у свою чергу створює нові можливості для розширення сфер і способів використання об'єктів права інтелектуальної власності, вираження їх у нових формах, зокрема цифровій. Позитивною рисою цифрової форми $€$ не лише спрощення тиражування та розповсюдження об'єктів інтелектуальної власності на матеріальних носіях, а й створення умов для їх передачі в електронних мережах. Розміщення об’єктів права інтелектуальної власності у Всесвітній мережі Їнтернет в умовах сьогодення стало чи не найбільш використовуваним способом їх поширення.

Як зазначено в Рекомендаціях парламентських слухань на тему: «Законодавче забезпечення розвитку інформаційного суспільства в Україні» (постанова Верховної Ради України від 3 липня 2014 р. № 1565-VII), сучасне суспільство характеризується якісно новими тенденціями розвитку в інформаційній сфері, насамперед стрімким формуванням глобального інформаційного простору та глобальним інформаційним протиборством, розробкою і використанням новітніх інформаційно-комунікаційних технологій, виникненням принципово нових суспільних відносин за різноманітними напрямами інформаційної діяльності.

Поява світової інфраструктури інформації поставила на порядок денний низку питань, які потребують негайного вирішення, оскільки мережа існує і досить активно розвивається. Володільці авторських прав стикаються зі значними ризиками, обумовленими існуванням інформаційних технологій. Транскордонний характер Їнтернету та цифрова форма фіксації розміщених в ньому творів значно ускладнюють здійснення авторами та їх правонаступниками своїх прав.

(C) Харитонова О. І.,, Ульянова Г. О., Кирилюк А. В., Симонян Ю. Ю.

Бааджи Н. П., Позова Д. Д., Григор'янц Г. Іे., Бурова Л. І̇., Мартинюк І̇. В., 2015 
Специфіка відносин у мережі Їнтернет з точки зору їх суб’єктного складу визначається такими чинниками. По-перше, невизначеністю місцезнаходження сторін, що зумовлює можливі проблеми з правом, що застосовується, а також з реальним виконанням зобов'язань. По-друге, складністю ідентифікації учасників відносин у мережі Їнтернет. По-третє, існування віртуальних організацій. Іे, нарешті, по-четверте, залежністю відносин між учасниками мережі Іेнтернет від відносин з інформаційними провайдерами.

Тому величезного значення набувають наукові розвідки, пов'язані зі сферою права інтелектуальної власності, зокрема, ті, що мають метою створення науково-теоретичного підгрунтя, формування доктрини інтелектуальної власності, що дозволить у подальшому більш ефективно регулювати відповідні відносини.

Однією з проблем теоретичного характеру, що потребують свого негайного вирішення, $є$ визначення правової природи Всесвітньої мережі Їнтернет, правовідносин, що виникають, кола учасників, їх специфіки, змісту тощо.

Слід зазначити, що питання визначення поняття і специфіки правовідносин, що виникають у Всесвітній мережі Їнтернет, є предметом наукового аналізу у численних публікаціях, кандидатських і навіть докторських дисертаціях [1-4]. Зокрема, існує точка зору, відповідно до якої інтернет-відносини - це особливі відносини, які виникають в результаті впливу норм міжнародного та інших галузей права, міжнародних договорів, рішень судів на поведінку людей і організацій (суб'єктів) [5, с. 145-149]. Крім того, І̇нтернет-відносини - це новий тип суспільних відносин, які виникають, змінюються і припиняються в кіберпросторі.

На нашу думку, визначення поняття та правової природи правовідносин, що виникають у мережі Їнтернет, неможливе без з'ясування сутності та юридичної природи самої мережі, а також специфіки суб'єктного та об'єктного складу відповідних правовідносин.

Отже, як уже зазначалось, в умовах становлення та розвитку інформаційного суспільства важливу роль відіграють інформаційно-комунікаційні технології, які дозволяють збирати, обробляти, отримувати та передавати інформацію на локальному, загальнодержавному та міжнародному рівнях. Провідне місце серед таких технологій посідає Їнтернет - найбільша телекомунікаційна мережа у світі, яка зародилася у 1969 році і починаючи з 80-х років ХХ століття стала активно розвиватися та розповсюджуватися. Процес глобальної інтернетизації не оминув і вітчизняний простір. Так, за результатами нещодавно проведеного компанією InMind Factum Group Ukraine дослідження, частка регулярних користувачів Їнтернету в Україні складає 59 \%, або 21,8 млн [6]. Попри надзвичайну популярність Їнтернету у вітчизняній юридичній науці приділено недостатню увагу дослідженню мережі як правової категорії, а також правовідносин, які виникають у зв'язку з іiі використанням. 
Перш за все, слід відзначити, що у міжнародних актах не надано визначення такому фундаментальному поняттю, як «інтернет». У Рекомендації Міжнародного союзу електрозв'язку (далі - MCE) з термінології глобальної інформаційної інфраструктури закріплене таке технічне визначення мережі Їнтернет: сукупність мереж, з’єднаних між собою 3 використанням протоколу Іेнтернет, що дозволяє їм функціонувати в якості єдиної великої віртуальної мережі. У затвердженому Радою МСЕ довіднику по мережах на базі протоколу İнтернет (IP) Їнтернет характеризується як логічна архітектура, незалежна від будь-якої конкретної мережі, але яка дозволяє забезпечувати міжмережеві з'єднання безлічі різних мереж таким чином, що комп'ютери і люди можуть здійснювати комунікацію, не обов'язково знаючи при цьому, яку мережу вони використовують або яким чином до них спрямовується інформація. Іेншими словами, Іेнтернет - це концептуальна розробка, яка включає протоколи і процедури, що потім використовуються вхідними в нього мережами для з'єднання між собою. Таке поняття закріплено у визначенні Федеральної мережевої ради Сполучених Штатів (Резолюція 1995 року), а також представлено Робочій групі Організації Об'єднаних Націй з управління використанням Їнтернету [7].

У прийнятому на 36-му пленарному засіданні Міжпарламентської Асамблеї держав - учасниць СНД (16 травня 2011 року) модельному законі «Про основи регулювання Іेнтернету» Їнтернет визначається як глобальна інформайно-телекомунікаційна мережа, яка поєднує інформаційні системи та мережі електрозв'язку різних країн за допомогою глобального адресного простору, яка грунтується на використанні комплексів інтернет-протоколів (Internet Protocol, IP) і протоколу передачі даних (Transmission Control Protocol, ТCР) та надає можливість реалізації різних форм комунікації, у тому числі розміщення інформації для невизначеного кола осіб. Модельне законодавство, як відомо, носить рекомендаційний характер та виконує роль своєрідного орієнтиру для національних органів законодавчої влади.

Що стосується чинного законодавства України, то визначення поняття «Іінтернет» закріплено у ст. 1 Закону України «Про телекомунікації», згідно з якою це - всесвітня інформаційна система загального доступу, яка логічно зв'язана глобальним адресним простором та базується на Іेнтернет-протоколі, визначеному міжнародними стандартами. При цьому під інформаційною системою загального доступу розуміється сукупність телекомунікаційних мереж та засобів для накопичення, обробки, зберігання та передавання даних.

Аналіз наведених дефініцій дозволяє дійти висновку, що всі вони характеризують Їнтернет переважно як технічний засіб передачі інформації. При цьому робиться акцент на технічній стороні функціонування мережі, залишаючи осторонь юридично значущі аспекти.

Говорячи про Їнтернет як правову категорію, слід зазначити, що в юридичній доктрині досі немає єдиного підходу щодо визначення його 
правової природи - як об'єкта права чи суб'єкта права, об'єкта чи предмета правового регулювання.

Так, розглядаючи потенційну можливість Їнтернету виступати в якості об’єкта права, більшість вчених, врешті-решт, доходять висновку про відсутність достатніх підстав для визнання такого твердження вірним з огляду на те, що Їнтернет у цілому не може належати кому-небудь одноособово на праві власності та бути об'єктом цивільного обороту. Дійсно, програмне забезпечення, яке використовується у мережі Інтернет, належить його розробникам; оцифровані твори науки, літератури, музичні виконання тощо, які розміщуються в Іेнтернеті, - суб'єктам авторського та суміжних прав; комп'ютерне обладнання, яке використовується для доступу в Їнтернет, - користувачам; сервери спеціалізованим компаніям. Їнтернет не $є$ об'єктом права як майно, інформація або об’єкти права інтелектуальної власності, Їнтернет не можна продати або купити.

С. В. Петровський, розглядаючи правову природу Їнтернету, не погоджується з принциповою неможливістю для Інтернету виступати в якості об’єкта цивільного обороту і належати одному власнику. Вчений підкреслює, що в даному випадку мова йде не про визнання виникнення в цивільному праві нового об’єкта, а про потенційну можливість наявності Їнтернету як різновиду майнового комплексу ознак об’єкта права [8, c. 15]. Разом із тим з такою точкою зору.навряд чи можна погодитися, оскільки в такому разі поняття мережі Їнтернет зводиться лише до сукупності технічних засобів, які забезпечують його функціонування. На наш погляд, мережа Їнтернет у цілому не $є$ ані матеріальним, ані нематеріальним благом, із приводу якого складаються певні правовідносини. Відповідні правовідносини виникають із приводу тих окремих об'єктів, які так чи інакше залучені до мережі Їнтернет у широкому іiі розумінні.

Що стосується наявності у мережі Їнтернет ознак суб'єкта права, то слід виходити з того, що мережі не притаманні такі загальноприйняті ознаки юридичної особи, як: організаційна єдність, наявність відокремленого майна, здатність брати участь у цивільному обігу від свого імені, деліктоздатність та здатність виступати позивачем або відповідачем у суді. І̇ якщо стосовно останніх трьох ознак не виникає сумнівів щодо їх неприйнятності як характеристики мережі Їнтернет, то щодо решти слід пояснити таке.

Про відсутність організаційного та структурного оформлення мережі Іेнтернет як певної організації свідчить той факт, що не існує єдиного управління мережею, немає однієї організації, яка б володіла, керувала б мережею Їнтернет або контролювала б ii.. Водночас існує низка некомерційних організацій, що забезпечують функціонування Їнтернету, серед яких, зокрема, Їнтернет-корпорація з присвоєння імен та номерів (ICANN), яка відповідає за глобальну координацію системи унікальних елементів мережі, іï стабільну роботу та безпечну організацію; Товариство Їнтернет, яке сприяє розвитку Їнтернету, розробці нових інтернет- 
технологій та забезпеченню доступності Всесвітньої мережі у світовому масштабі; Рада з архітектури Іेнтернет (IAB), яка здійснює нагляд за архітектурою Їнтернету, у тому числі його протоколами та пов'язаними 3 ними процедурами, та за створенням нових стандартів Їнтернету i включає в себе інженерну групу, яка займається вирішенням технічних проблем Їнтернету (IETF), та дослідницьку групу (IRTF). При цьому у мережі Їнтернет відсутня майнова самостійність, оскільки, як зазначалося вище, матеріальні (технічні) та нематеріальні ресурси мережі належать різним суб’єктам. Побутує також думка, що всі користувачі, які беруть участь в опосередкованій Їнтернет-технологіями комунікації, становлять товариство Інтернет як соціальну структуру. Разом із тим немає достатніх підстав для ототожнення з Їнтернет-спільнотою усієї мережі Їнтернет і у такий спосіб наділення іï властивостями суб'єкта права.

Заперечуючи наявність у Їнтернету в цілому ознак об'єкта та суб'єкта права, В.О. Копилов порівнює його зі звичайним матеріальним (реальним) середовищем та застосовує для його дослідження модель інформаційної сфери [9, с. 94].

İ. М. Рассолов позначає сукупність суспільних відносин, що виникають у процесі використання Інтернету та інших мереж, що складаються із приводу інформації, яка обробляється за допомогою ЕОМ, терміном «кіберпростір». При цьому об’єктом цих відносин виступає не будь-яка інформація, а тільки та, яка перебуває в обігу в Мережі. Розмірковуючи над питанням, що саме регулює позитивне право - суспільні відносини або сам кіберпростір, вчений робить висновок, що позитивне право впливає на суспільні відносини суб'єктів (людей) у процесі здійснення ними своєї діяльності з використанням світової інфраструктури Іेнтернету $[10$, с. 10,12$]$.

С. В. Малахов стверджує, що Їнтернет не $є$ ані об'єктом цивільних прав, ані суб'єктом цивільних правовідносин та не належить повністю до предмета цивільно-правового регулювання, виступаючи об'єктом правового впливу норм різних галузей права. При цьому переважна більшість суспільних відносин, що формуються, розвиваються і реалізуються в Їнтернеті, включаються до предмета цивільно-правового регулювання [11, с. 13]. У цілому з такою точкою зору можна погодитися, проте з певними зауваженнями.

Дійсно, виходячи із загальновизнаних положень теорії права, предмет правового регулювання становлять суспільні відносини, у той час як об’єктом правового регулювання $€$ будь-який предмет пізнання - матеріальний чи нематеріальний. Як зазначає Ю. Іे. Гревцов, предмет правового регулювання - це конкретні об'єкти, межі, елементи об'єкта правового регулювання [12, с. 52]. Разом із тим у правовій науці існує дискусія щодо співвідношення категорій «правовий вплив» та «правове регулювання», в ході якої висловлюються такі основні дві точки зору: 1) правове регулювання вичерпує можливі форми впливу права на 
суспільні відносини, тобто зазначені категорії є тотожними (С. О. Голунський, О.А. Лукашева, Л.С.Явич та ін.); 2) поняття «правовий вплив» за обсягом $€$ ширшим за поняття «правове регулювання» (С. С. Алексєєв, М. І̇. Матузов, О. В. Міцкевич, М. Ф. Орзіх, Ю. К. Толстой та ін). Прихильники другого підходу зазвичай визначають правове регулювання як здійснюваний всією системою юридичних засобів вПлив на суспільні відносини з метою їх упорядкування, а правовий вплив як взятий у єдності та різноманітності весь процес впливу права на соціальне життя, свідомість та поведінку людей. При цьому до предмета правового впливу включаються і такі економічні, політичні, соціальні відносини, які правом не регулюються, але на які так чи інакше воно поширює свій вплив [13, с. 230]. Поділяючи таку точку зору, вважаємо за можливе визначити правову природу мережі Їнтернет саме як об'єкта правового впливу, у той час як у зв'язку з використанням мережі Їнтернет виникають різноманітні суспільні відносини, які становлять предмет правового регулювання різноманітних галузей права.

Відзначимо основні характеристики мережі Їнтернет, які, на наш погляд, мають значення для розуміння сутності цього явища та дозволять сформулювати визначення Їнтернету як правової категорії.

По-перше, Їнтернет $є$ інформаційно-телекомунікаційною мережею. Як справедливо зазначає С. В. Петровський, термін «інформаційна мережа», який іноді використовується для позначення Їнтернету, є не зовсім вдалим, оскільки не уточнює ні форму інформації, що передається, ні суб'єктів передачі та може охоплювати як технічні (телефонний, телеграфний та інші мережі), так і соціальні (агентурні, бізнес-спільноти тощо) утворення, що здійснюють передачу інформації [8, с. 10]. Разом із тим окрім Інтернету існують й інші мультисервісні мережі, які також грунтуються на протоколі IP, наприклад Next Generation Network. У зв'язку з цим у літературі справедливо звертається увага на важливість визначення на технічному рівні відмінностей Іेнтернету від інших схожих з ним мереж, які використовують аналогічні програмні засоби і технології, але не $є$ Іेнтернетом [14].

По-друге, Їнтернет є глобальною ком’ютерною мережею, яка поєднує десятки мільйонів користувачів по всьому світу у понад 150 країнах, використовуючи різноманітні канали зв'язку.

По-третє, мережа Їнтернет передбачає всезагальний доступ користувачів. Прийняті на 32-й сесії Генеральної конференції ЮНЕСКО Рекомендації щодо розвитку та використання багатомовності та загального доступу до кіберпростору передбачають низку заходів з метою забезпечення такого доступу: вироблення відповідної політики державами-членами і міжнародними організаціями; створення на місцевому, національному, регіональному та міжнародному рівнях механізмів, що сприяють загальному доступу до Іेнтернету за допомогою доступних цін на телекомунікаційні та Іेнтернет-послуги; спонукання інтернет-провайдерів до надання пільгових тарифів на доступ до Їнтернету окремим категоріям користувачів. 
Крім того, право на доступ до Їнтернету як універсальну (загальнодоступну) послугу закріплює Директива Європейського Союзу про універсальну послугу в редакції 2009 року (2009/136/ЕС), яка встановлює, що кожен в $Є С$ повинен мати доступ до мінімального переліку електронно-комунікаційних послуг доброї якості і за доступною ціною, включаючи доступ до Їнтернету. В юридичній літературі навіть порушується питання про визнання права на доступ до мережі Їнтернет в якості самостійного конституційного (основного) права людини [15, с. 45].

У законодавстві України загальнодоступні (універсальні) телекомунікаційні послуги визначені як мінімальний набір певних послуг нормованої якості, доступний усім споживачам на всій території України. Разом із тим передбачений статтею 62 Закону України «Про телекомунікації» перелік таких послуг не містить згадки про доступ до Їнтернету. Звісно, така ситуація $є$ неприйнятною і потребує приведення у відповідність до міжнародних рекомендацій та стандартів Європейського Союзу.

По-четверте, одним із принципів обміну інформацією в Іेнтернеті $є$ принцип анонімності, закріплений у Декларації про свободу комунікацій в Їнтернеті, прийнятій Комітетом міністрів Ради Європи 28 травня 2003 року. Анонімність означає, що з метою забезпечення свободи вираження поглядів та обміну інформацією і захисту від мережевого стеження слід поважати волю користувача не розкривати свою особистість. 3-поміж інших проголошених у Декларації принципів - правила щодо змісту (контенту) для Їнтернету; саморегуляція або спільна регуляція; відсутність попереднього державного контролю; ліквідація бар'єрів для участі індивідів в інформаційному співтоваристві; свобода надання послуг через Іेнтернет; обмежена відповідальність постачальників послуг за зміст інформації.

Разом із тим попри проголошений принцип анонімності повсякчасно виникає питання ідентифікації користувачів глобальної мережі, операторів послуг, які надаються з використанням Їнтернету, а також володільців розміщеної на просторах Їнтернету інформації. Вирішення цього питання край необхідне з точки зору запобігання вчиненню протиправних дій у мережі та забезпечення можливості правового регулювання тих відносин, які виникають у віртуальному просторі та за своєю суттю потребують такого регулювання. У зв'язку з цим на міжнародному рівні мають бути чітко визначені межі допустимої анонімності в мережі Їнтернет та окреслені випадки іiі законодавчого обмеження.

По-п’яте, мережа Їнтернет має складну багаторівневу інфраструктуру. Так, за словами М. В. Якушева, Їнтернет - багатошарове, багаторівневе утворення, об'єднання багаторівневих мереж На самому нижньому рівні - фізична інфраструктура, канали зв'язку, інфраструктура доступу до мереж. Далі розташовується адресний простір (IP-адреси), над яким існує надбудова у вигляді доменних імен, система DNS, та на самих верхніх поверхах ієрархії Їнтернету як мережі знаходяться звичайні додатки, поштові сервіси, пошукові системи, веб-сайти [16]. При 
цьому функціонування базових компонентів такої інфраструктури підпадає під юрисдикцію окремих держав, в яких закріплюється правовий режим об'єктів інфраструктури та порядок їх використання [17, с. 138]. В основі архітектури мережі відповідно лежить принцип багаторівневої передачі повідомлень: на самому верхньому рівні еталонної моделі взаємодії відкритих систем ISO/OSI відбувається формування повідомлення, яке при передачі проходить всі рівні системи до найнижчого (фізичного), на якому передається адресату.

По-шосте, функціонування Інтернету має транскордонний характер, що зумовлює необхідність транскордонного управління мережею з одночасним регулюванням у межах національних юрисдикцій питань використання Інтернету. Так, виконання функцій з управління кореневою зоною системи доменних імен верхнього рівня (DNS), координації розподілу глобального пулу IP-адресного простору і номерів портів регіональним Їнтернет-реєстрам, а також забезпечення зберігання та розподілу імен та номерів Їнтернет-протоколів реєстрів покладено на Адміністрацію адресного простору Їнтернету (Internet Assigned Numbers Authority, IANA). Крім того, в число ключових організацій, які беруть участь у транскордонному управлінні технологічною інфраструктурою Іेнтернету, входять п’ять регіональних Їнтернет-реєстраторів, які відповідають за призначення IP-адрес кінцевим користувачам на певних територіях, а також локальні Їнтернет-реєстратори, такі як Їнтернет-провайдери. Адміністрування адресного простору українського сегмента мережі Їнтернет здійснюється об'єднанням підприємств «Український мережевий інформаційний центр» (UANIC) у координації з міжнародною системою адміністрування мережі Їнтернет.

Слід також відзначити, що в загальновизнаному визначенні поняття «управління Їнтернетом», розробленому робочою групою при Генеральному секретарі ООН, втілений так званий «підхід усіх зацікавлених сторін», суть якого полягає в такому. Окрім органів влади національних держав, міжнародних міжурядових організацій, в управлінні Їнтернетом беруть участь також «приватний сектор» (комерційні організації, бізнесспільнота та ін.) та громадянське суспільство (технічні та академічні товариства, експерти та ін.) [18, с. 19].

По-сьоме, екстериторіальний характер побудови та функціонування мережі Їнтернет зумовлює необхідність поєднання міжнародного та національного правового регулювання.

На цей час міжнародно-правове регулювання відносин у мережі Їнтернет здійснюється через засоби так званого «м'якого права» у вигляді різноманітних рекомендацій, резолюцій та декларацій, що видаються міжнародними організаціями (Міжнародний союз електрозв'язку, Всесвітня організація інтелектуальної власності, ООН, ЮНЕСКО, Рада Європи, Їнтернет корпорація з присвоєння імен та номерів та ін.). Положення таких документів формально не є обов'язковими, і їхнє дотримання з боку держав грунтується виключно на авторитеті тих суб'єктів, 
що їх приймають. Разом із тим наразі існує потреба у прийнятті міжнародного договору, в якому б були урегульовані питання поняття мережі Інтернет, її правового режиму, структури, застосованого права, урегулювання спорів, а також інші аспекти функціонування мережі на національному, регіональному і глобальному рівнях. Звісно, подібне регулювання мережі Їнтернет та відносин, які в ній виникають, мають враховувати покладені в основу функціонування мережі принципи децентралізації та саморегулювання.

Поряд із міжнародно-правовим регулюванням на рівні національного законодавства підлягають регламентації об'єкти фізичного рівня інфраструктури мережі Їнтернет, а також різноманітні відносини, які виникають у зв'язку з ії використанням.

На підставі викладеного, хотілося б запропонувати таке визначення мережі Їнтернет як правової категорії: Їнтернет - це глобальна загальнодоступна інформаційно-телекомунікаційна мережа зі складною багаторівневою інфраструктурою, яка функціонує на засадах транскордонного управління та надає можливості для створення, розміщення інформащії $i$ доступу до неї, а також надання пов'язаних із иим інформащійних послуг.

Визначившись із сутністю мережі Їнтернет як правової категорії, слід, на нашу думку, встановити об'єкти, щодо яких виникають відповідні відносини, та суб'єктів, що діють у цьому просторі, з метою визначення поняття та видів правовідносин у мережі Їтернет.

Говорячи про об'єкти права інтелектуальної власності в мережі Іेнтернет, слід зазначити, що серед численної інформації, яка заповнює всесвітню мережу Їнтернет, на особливу увагу заслуговують результати інтелектуальної, творчої діяльності. Поява мережі Їнтернет привнесла чимало суттєвих змін у сфері інтелектуальної власності, в тому числі стосовно об'єктів інтелектуальної власності, обумовивши появу нових результатів творчої діяльності, зміну об'єктивної форми вираження вже існуючих об’єктів тощо. Внаслідок зазначених процесів актуального значення набуло питання визначення правового режиму об'єктів права інтелектуальної власності в мережі Їнтернет.

Слід зазначити, що поряд з активними пошуками оптимальних шляхів вирішення проблеми ефективного захисту прав інтелектуальної власності в мережі Їнтернет та боротьби з порушниками обгрунтовується точка зору про необхідність спрощення процедури доступу користувачів до результатів авторського права і суміжних прав у мережі. Так, А. Черкасов зазначає, що все частіше в країні і за кордоном висловлюється думка про те, що дотримання авторських прав в Їнтернеті гальмує розвиток Мережі, заважає іï активному інформаційному наповненню. Прихильники таких поглядів пропонують обмежити або навіть вилучити ряд норм $з$ концептуальних основ авторського права, наприклад, розширити можливості вільного використання творів. Однак саме відсутність реального захисту прав нерідко утримує авторів від розміщення в ме- 
режі своїх матеріалів. І̇ якщо прийняти вказані доповнення, то це де-юре перетворить Їнтернет в чорну діру для інтелектуальної праці, наслідки чого позначаться на відносинах не тільки у віртуальному світі, але й у світі реальному [19].

Не заперечуючи важливого практичного значення дослідження теоретичних і практичних аспектів захисту прав інтелектуальної власності в мережі Їнтернет, вважаємо за необхідне звернутись в першу чергу до визначення категорій об'єктів права інтелектуальної власності, які поширюються в мережі.

Об'єкти права інтелектуальної власності - це результати інтелектуальної, творчої діяльності, виражені в об’єктивній формі або зафіксовані на певному матеріальному носії, у тому числі електронному, які відповідають критеріям охороноздатності, встановленим у законодавстві.

У законодавстві, яке регулює відносини інтелектуальної власності, не закріплено визначення категорії «об'єкт інтелектуальної власності», натомість наведено невичерпний перелік об'єктів, а також надано визначення окремих об'єктів, переважно шляхом перерахування їх основних ознак, критеріїв охороноздатності.

Згідно із ст. 420 Цивільного кодексу України до об’єктів права інтелектуальної власності, зокрема, належать: літературні та художні твори; комп'ютерні програми; компіляції даних (бази даних); виконання; фонограми, відеограми, передачі (програми) організацій мовлення; наукові відкриття; винаходи, корисні моделі, промислові зразки; компонування (топографії) інтегральних мікросхем; раціоналізаторські пропозиції; сорти рослин, породи тварин; комерційні (фірмові) найменування, торговельні марки (знаки для товарів і послуг), географічні зазначення; комерційні таємниці.

Кожний $з$ наведених у законодавстві об’єктів інтелектуальної власності може бути вільно використаний в мережі Їнтернет, причому як зі згоди правоволодільця, так і без його відома.

Враховуючи численність результатів інтелектуальної власності, які можуть бути використані в мережі Їнтернет, вважається необхідним навести їх класифікацію.

Відповідно до ст. 433 Кодексу, ч. 2 ст. 8 Закону про авторське право твори є об'єктами авторського права незалежно від їх завершеності, призначення, цінності тощо, а також способу чи форми їх вираження.

У першу чергу, результати інтелектуальної діяльності, які отримали поширення в мережі Інтернет, вважається доцільним розподілити залежно від їх правового регулювання на дві категорії:

- передбачені чинним законодавством, до яких віднесено результати інтелектуальної діяльності, створення, охорона, захист яких визначено у нормативно-правових актах;

- не передбачені серед об'єктів права інтелектуальної власності, однак які за своєю суттю $є$ результатом інтелектуальної, творчої діяльності (наприклад, реклама). 
По-друге, поширеним є поділ об’єктів інтелектуальної власності на чотири категорії залежно від сфери, мети створення та використання, умов правової охорони:

- об'єкти авторського права і суміжних прав;

- об'єкти права промислової власності (патентного права);

- засоби індивідуалізації учасників цивільного обігу, товарів, робіт та послуг;

- нетрадиційні об'єкти права інтелектуальної власності.

По-третє, залежно від правомірності розміщення об'єктів права інтелектуальної власності можливо виділити:

- об'єкти, розміщені правомірно (без порушення майнових та немайнових прав інтелектуальної власності);

- об’єкти, розміщені неправомірно (з порушенням майнових та/або немайнових прав інтелектуальної власності).

По-четверте, залежно від умов використання об'єктів права інтелектуальної власності, вони можуть бути поділені на;

- об’єкти з обмеженим доступом (розміщення лише частини твору, обмеження можливості копіювання тощо);

- об'єкти з повним доступом та можливістю використання.

По-п'яте, залежно від взаємозв'язку об'єктів права інтелектуальної власності з функціонуванням мережі Їнернет вони можуть бути поділені на дві категорії:

- об'єкти, поява яких обумовлена функціонуванням мережі Їнтернет;

- об'єкти, не пов'язані з функціонуванням мережі.

Враховуючи тематику дослідження, вважається доцільним більш детально зупинитись на об'єктах, які забезпечують функціонування мережі Їнтернет. До таких об'єктів слід віднести веб-сайти та доменні імена, особливість яких полягає в тому, що вони забезпечують можливість розміщення інформації в мережі. Не менш важливе значення для забезпечення поширення інформації в мережі Їнтернет, у тому числі й об’єктів права інтелектуальної власності, мають і комп'ютерні програми. Специфіка кожного із зазначених об'єктів права інтелектуальної власності обумовлює необхідність вироблення спеціальних умов їх охорони та правил використання.

У першу чергу слід відзначити, що найбільш врегульованими, як за законодавством окремих держав, так і на міжнародному рівні, $є$ відносини, що виникають з приводу використання, охорони та захисту комп’ютерних програм. Відповідно до Директиви Ради Європейських Співтовариств від 14 травня 1991 р. «Про правову охорону комп'ютерних програм» (91/250/ ЄEC) [20] комп'ютерні програми охороняються як літературні твори в тому значенні, як цей термін розуміється в Бернській конвенції про охорону літературних і художніх творів. Охорона комп'ютерних програм як літературних творів передбачена також у Цивільному кодексі України (ст. 433) [21] і Цивільному кодексі Російської Федерації (ст. 1259) [22]. 
Основна позитивна риса охорони за допомогою механізму авторського права полягає в презумпції авторства: тобто авторське право на комп'ютерну програму виникає при ії створенні і для його реалізації не потрібно обов'язкової реєстрації програми. Реєстрація може бути проведена за бажанням автора, носити формальний характер і не вимагає багато часу. $\Theta$ й негативні риси такої охорони. В першу чергу, це тривалий термін охорони. На відміну від літературних творів, текст комп'ютерної програми (вихідний чи об'єктний код) не має самостійної цінності без можливості її застосування в комп'ютері. Отже, сприйняття комп'ютерної програми, тобто, власне кажучи, ії тексту, відбувається не безпосередньо людиною, а опосередковано, за допомогою комп'ютера [23]. У зв'язку з цим у наукових дослідженнях обгрунтовується необхідність створення спеціального механізму правової охорони комп'ютерної програми, одним з основних ознак якого $€$ комплексність сучасної комп'ютерної програми як об'єкта, яка дозволяє застосовувати норми авторського права і права промислової власності в процесі правової охорони окремих елементів комп'ютерної програми [24, с. 15].

Доцільність захисту прав на комп'ютерні програми в рамках права промислової власності обгрунтовується тим, що механізм патентного захисту більш гнучкий, ніж механізм авторських прав, оскільки дозволяє захищати розробки різного технологічного рівня різними документами (методики і технології - патентами, впроваджені технічні рішення і доопрацювання - авторськими свідоцтвами та сертифікатами) [25].

Важливе значення має також забезпечення належної охорони прав на доменні імена. Домен індивідуалізує сайт, саме за доменним іменем споживач може знайти той чи інший сайт, особу, товар або послугу. Це дозволяє говорити про самостійне значення і правову регламентацію доменних імен. На відміну від комп'ютерної програми, доменні імена не знайшли чіткого закріплення в системі об’єктів права інтелектуальної власності. Як правило, положення про доменні імена закріплені в законодавстві, що регулює охорону прав на торговельні марки. Так, відповідно до Закону України «Про охорону прав на знаки для товарів і послуг» використанням торгової марки визнається в тому числі застосування ії в доменних іменах. При цьому використання без згоди власника зареєстрованого знака або позначення, схожого зі знаком, в доменних іменах визнається порушенням прав власника свідоцтва на торговельну марку [26].

Відповідно до умов «Правил домена.UA» з метою захисту законних інтересів членів Інтернет-спільноти України щодо їх інтелектуальної власності, приватні доменні імена другого рівня в домені .UA делегуються виключно у тому випадку, коли відповідне доменне ім'я повністю, або його компонент другого рівня (до знака «.», але не включаючи цей знак), за написанням збігається із Знаком, права на використання якого на території України належать відповідному реєстранту [27].

Аналіз сучасних тенденцій в галузі присвоєння доменних імен свідчить про те, що товарні знаки в доменних іменах в даний час широко 
використовуються для створення у споживачів асоціативного зв'язку між діяльністю фірми та її сайтом в Їнтернеті. У підсумку, доменне ім'я також фактично стає засобом індивідуалізації. Негативним моментом $€$ те, що популярністю відомих товарних знаків і легкістю реєстрації доменного імені найчастіше користуються кіберсквотери (загарбники доменних імен). Вони реєструють на себе доменне ім'я, аналогічне товарному знаку якої-небудь широковідомої фірми з метою подальшого продажу зареєстрованого доменного імені цій самій фірмі. Переважно такому захопленню підлягають доменні імена другого рівня, що пов'язано зі зручністю їх запам'ятовування [28].

Слід зазначити, що крім торгових марок, важливе значення для індивідуалізації учасників цивільного обороту мають комерційні найменування, які також можуть використовуватися при складанні доменних імен. Крім того, існують проблеми, пов'язані з використанням в доменних іменах прізвищ та псевдонімів без згоди їх власників. Використання об’єктів інтелектуальної власності у складі доменного імені $€$ тільки однією стороною проблеми. 3 іншого боку, на нашу думку, самі доменні імена слід розглядати як потенційний об’єкт незаконних посягань з боку недобросовісних користувачів. Наприклад, оригінальне доменне ім'я, яке не містить в собі елементів торгової марки або комерційного найменування, але отримало популярність в мережі Їнтернет, може незаконно реєструватися іншими користувачами. Враховуючи постійне зростання числа торгових марок, комерційних найменувань, проблема реєстрації доменних імен добросовісними користувачами набуватиме все більшої актуальності. На нашу думку, доменне ім'я має розглядатися як самостійний об'єкт права інтелектуальної власності, а не як один із способів використання торгової марки. Зокрема, доменні імена можуть бути віднесені до засобів індивідуалізації учасників цивільного обороту з урахуванням особливостей, обумовлених порядком їх реєстрації та використання.

Не менш важливе значення має охорона веб-сайтів. Веб-сайт не розглядається за законодавством України як самостійний об’єкт права інтелектуальної власності. На нашу думку, веб-сайт слід розглядати як самостійний об'єкт права інтелектуальної власності, хоча і не передбачений чинним законодавством, але який заслуговує на належну охорону та захист від незаконних посягань.

3 метою привернення уваги користувачів мережі Їнтернет, власники сайтів намагаються створити їх більш яскравими, оригінальними і зручними для перегляду інформації. Разом з тим власники сайтів не можуть бути застраховані від недобросовісних дій, пов'язаних із копіюванням як інформації, розміщеної на сайті, так і самого оформлення сайта і використання їх на інших веб-сайтах.

У листі Міністерства юстиції України від 18 грудня 2006 р. № 19-5-537 зазначено, що на законодавчому рівні чітко не встановлено, що веб-сайт відноситься до комп'ютерних програм [29]. 
Більш повно питання віднесення веб-сайта до тих чи інших об’єктів права інтелектуальної власності розкрито у листі Державного департаменту інтелектуальної власності Міністерства освіти і науки України від 22 січня 2007 р. [30].

По-перше, виходячи 3 того, що сайтом $€$ певний набір текстової та графічної інформації, баз даних, аудіо- та відеоматеріалів, він може бути визнаний самостійною базою даних.

По-друге, сторінка сайта має свою унікальну адресу в мережі Їнтернет і $€$ написаною за допомогою команд мови HTML своєрідною програмою, за допомогою якої здійснюється управління формуванням зображення сторінки при доступі до неї користувача, самого процесу навігації та інших завдань, поставлених перед конкретним веб-ресурсом. Якщо програма, розроблена для користування сайтом $€$ оригінальною, відповідно до закону «Про авторське право і суміжні права» може отримати охорону і бути зареєстрованою як комп'ютерна програма.

По-третє, веб-сайт може бути представлений в унікальному дизайнерському виконанні, коли використовуються не готові шаблони і форми, графічні об’єкти, доступні для безкоштовного використання в самій мережі Їнтернет, а здійснюється творча робота з розробки спеціальних шрифтів, створення та підбору кольорового вирішення сайта, виконання написів та інших ефектів, створюються унікальні рішення елементів навігації по сайту. У такому випадку, веб-сайт може отримати охорону як складний об'єкт авторського права. Крім того, оригінальне оформлення сайта може отримати охорону як промисловий зразок, який $є$ об'єктом промислової власності.

Таким чином, по-перше, веб-сайт може підлягати охороні як складний об'єкт авторського права; по-друге, охороні можуть підлягати окремі елементи веб-сайта, як комп'ютерна програма, бази даних, промисловий зразок.

Таким чином, незважаючи на те, що не всі об’єкти права інтелектуальної власності, які використовуються в мережі І̇нтернет, виділені на законодавчому рівні як самостійні, такі об'єкти або їх окремі складові можуть отримати охорону як об'єкти авторського права або права промислової власності за умови відповідності вимогам охороноздатності, передбаченим у законодавстві [31, с. 94].

При визначенні суб'єктного складу відносин, що виникають у мережі Їнтернет, слід пам'ятати про те, що віртуальний простір $€$ новим людським і технологічним середовищем, яке, з одного боку, складає спільність великої кількості осіб, з різноманітністю культур, мов та професій, які пропонують та запитують інформацію, а з іншого боку, всесвітню комп'ютерну мережу, яка з'єднує їх завдяки інфраструктурам телекомунікацій. В юридичній науці під суб'єктами правовідносин розуміються окремі особи та організації, які згідно з нормами права $€$ носіями суб'єктивних юридичних прав і обов'язків. Природа діяльності в кіберпросторі, утворюваному зв'язком віддалених комп'ютерів, дає підстави для 
класифікації цих суб'єктів на активних (користувачів та власників інформаційних ресурсів (сайтів) та пасивних (інформаційних посередників (провайдерів).

Коло суб'єктів - учасників інформаційних контактів і процесів охоплює все різноманіття учасників зв'язку та інформаційної взаємодії безлічі суб'єктів, крім основних сторін конкретних відносин. В інформаційному просторі і процесах діє безліч посередників - провайдерів або операторів в системі мережі контенту та ін. - суб'єктів, що надають нові види послуг. Ця безліч суб’єктів формує поля різних інтересів, свобод, прав і обов'язків. Види, форми і міри відповідальності різних суб'єктів повинні бути пов'язані в системі і збалансовані не тільки в національному праві, але і в планетарному масштабі. Фахівці і практики відзначають, що ми перебуваємо тільки на початку усвідомлення цих проблем і що попереду непочатий край роботи. Фахівцями з проблем правової інформатизації на сучасному етапі приділяється увага такому фактору у сфері Їнтернету, як віртуалізація суб'єктів і віртуалізація відносин в системі глобальної інформаційної взаємодії різних структур [32, с. 254].

Розглядаючи окремі види інформаційної діяльності, які здійснюються в межах або за допомогою мережі Їнтернет, насамперед слід виділити їх неоднорідність. Тому правовідносини, що виникають, досить важко узагальнити. Навпаки, деякі дослідники акцентують увагу на необхідності запровадження певної класифікації як самих правовідносин, що виникають у мережі Їнтернет, так і суб'єктів цих правовідносин. Загалом сама ідея подібної диверсифікації $є$ дуже слушною, але за основу все ж слід брати не стільки функціональну спрямованість діяльності того чи іншого суб'єкта, скільки правовий матеріал, яким відповідна діяльність регламентується [9].

У науковій літературі пропонується декілька класифікацій суб’єктів.

Так, зокрема, до суб'єктів правовідносин в Їнтернеті відносять:

- постачальників послуг доступу в Їнтернет;

- постачальників інформації;

- користувачів.

Подібна класифікація суб'єктів суспільних відносин, що складаються у сфері Їнтернету, запропонована Ю. М. Батуріним. У книзі «Телекомунікації й право: питання стратегії» він виділяє так званий чотирикутник суб'єктів телекомунікаційних відносин:

- оператори зв'язку;

- постачальники послуг доступу до Їнтернету;

- постачальники інформації;

- користувачі [33].

Пропонується виділяти щонайменше три групи суб'єктів, які діють в мережі Їнтернет.

Першу групу суб'єктів, що здійснюють інформаційну діяльність в Іेнтернеті, становлять оператори і провайдери телекомунікацій. Вони за- 
безпечують саме функціонування мережі Їнтернет як інформаційної системи, їх діяльність охоплює: технічне обслуговування і експлуатацію технічного обладнання телекомунікаційних мереж, надання в користування ліній зв'язку, реєстрацію та адміністрування адрес мережі Їнтернет тощо.

Їнтернет-провайдери (від англ. to provide - забезпечувати, надавати доступ) - це організація, яка надає послуги доступу та передачі інформації певними інформаційними каналами.

Слід зазначити, що ця категорія суб’єктів, на відміну від інших, відрізняється своєю розгалуженістю та складністю.

Так, провайдери поділяються на первинних, які забезпечують саме вихід у світовий Інтернет у світових пунктах обміну трафіком.

Провайдери першого рівня, іншими словами, первинні регіональні провайдери послуг, хоч і надають послуги з доступу до ресурсів Їнтернету, але мають регіональний характер, адже сфера надання їх послуг обмежена певною територією і вони не $є$ самостійними в наданні послуг, адже користуються послугами закордонних компаній, тобто послугами первинних провайдерів.

Третю групу складають провайдери другого та третього рівнів, середні, малі і т.д. До третьої групи найчастіше відносять провайдерів, які орендують канали різної пропускної спроможності в інших провайдерів. Особливістю та специфікою роботи цієї категорії суб'єктів $€$ те, що на них покладається завдання забезпечення постійної наявності вільних модемних виходів та забезпечення охорони електронної пошти, швидкість передачі даних, рівень технічної підтримки, додаткові послуги, які надаються Їнтернет-провайдерами. Ще однією специфікою, і напевно найважливішою, $є$ те, що саме на цю категорію покладається відповідальність за порушення авторських прав, іншими словами Їнтернет-провайдери несуть відповідальність за достовірність переданої інформації, і при отриманні відомостей про незаконність змісту переданої інформації на них покладається завдання здійснення своєчасних дій для запобігання доступу до такої інформації.

При цьому слід чітко відрізняти два таких поняття, як доведення до загального відома та надання технічних засобів для передання. Дії Їнтернет-провайдерів не можуть розумітися як доведення до загального відома, адже це автоматично покладений на Їнтернет-провайдерів обов'язок перевіряти всю інформацію, що проходить через їх інфраструктуру, а це $\epsilon$ мало можливим. Їншими словами, провайдер надає абоненту тільки можливість користуватися його технічним обладнанням для доступу до мережі Їнтернет та надає послуги щодо користування мережею Іेтернет.

Основними видами інформаційних послуг, які надаються цими суб'єктами, є:

1) підключення, тобто забезпечення доступу до мережі Їнтернет;

2) хостинг - розміщення інформації та інформаційних ресурсів замовника на відповідному технічному обладнанні - веб-серверах і забезпечення доступу до цих ресурсів через Їнтернет; 
3) адміністрування - здійснення організаційно-технічних заходів для забезпечення функціонування технічних засобів підтримки адресного простору Їнтернет;

4) послуги з навігації в Їнтернеті - створення так званих веб-порталів, які полегшують пошук і доступ до інформаційних ресурсів мережі Їнтернет.

У зв'язку з цим інтернет-провайдери поділяються на типи відповідно до наданих послуг.

Провайдер доступу - провайдер, що передає маршрутизуючий матеріал або надає з'єднання для передачі матеріалу через систему або мережу, контрольовану або керовану ним, до чого прирівнюється проміжне зберігання матеріалу в цілях зазначеної передачі, маршрутизації або надання з'єднання [34, с. 498].

Провайдери доступу «безмежно далекі» від змістовного боку здійснюваних при їх посередництві інформаційних транзакцій.

У свою чергу, провайдери доступу можуть бути поділені за функціонально-географічною ознакою на такі види:

- магістральний провайдер (Internet Backbone Provider - IBP оператор міжрегіональних IP-мереж, що забезпечує переміщення інтернет-трафіка між регіонами країни, а також за кордон і взаємодіє не з користувачами Їнтернету, а регіональними та/або місцевими інтернет-провайдерами), що має магістральні канали зв'язку у власності;

- кінцевий провайдер (ISP), що діє на регіональному і локальному рівні і забезпечує надання інтернет-послуг користувачам Іेнтернету.

Діяльність цієї групи суб'єктів визначається насамперед національними та міжнародними нормативно-правовими актами, що регулюють питання електрозв'язку, телекомунікацій, надання інформаційних послуг тощо.

До другої групи суб'єктів належать виробники, власники та розповсюджувачі інформації та інформаційних ресурсів, тобто суб'єкти, які створюють інформаційне наповнення мережі Інтернет. Ці суб'єкти створюють електронні інформаційні ресурси, володіють правами на них або на окремі документи, що входять до їх складу, та забезпечують функціонування електронних інформаційних ресурсів і задоволення інформаційних потреб користувачів.

Окремо слід виділити групу суб'єктів, яка надає специфічні послуги щодо укладання цивільно-правових угод за допомогою мережі Їнтернет (Їнтернет-магазини, Іेнтернет-казино, Їнтернет-аукціони, платні інформаційні послуги тощо), тобто все, що охоплюється терміном e-commerce (електронна комерція).

Діяльність суб'єктів цієї групи регулюється насамперед цивільним законодавством і законодавством про інтелектуальну власність та авторські права. Щодо електронної комерції, то, незважаючи на неврегульованість цієї сфери в національному законодавстві, слід зазначити, що Іेнтернет виступає лише засобом комунікациї між продавцем і споживачем, подібним до телефонного або поштового зв'язку. 
Останню, третю групу суб'єктів становлять споживачі телекомунікаційних послуг. Споживачем може бути юридична або фізична особа, яка потребує, замовляє або отримує телекомунікаційні послуги для власних потреб. Основними видами послуг, які надаються користувачам мережі Їнтернет, є: підключення, доступ до інформаційних ресурсів, хостинг та електронна пошта.

Аналіз суб'єктного складу суспільних відносин, що виникають у зв'язку з використанням Їнтернету, приводить до висновку про те, що даний суб'єктний склад «слабо корелює» з видами суб'єктів правовідносин. Так, в Їнтернеті не принципово, чи $є$ користувач мережі фізичною або юридичною особою, або чи зареєстрований оператор мережевих послуг в якості платника податків.

Причому це стосується не тільки таких суб'єктів правовідносин, як фізичні та юридичні особи. Як суб'єкти правовідносин можуть виступати і органи державної влади, а також органи місцевого самоврядування. Оскільки доступ в Їнтернет в даний час $€$ анонімним, то у низці випадків визначення приналежності суб'єкта до традиційних в реальному світі суб'єктів видається складним.

Наприклад, при наданні послуг пошукової інформаційної бази даних в Їнтернеті (типу Рамблер, Яндекс) власник цієї бази даних не може визначити, до якої категорії суб'єктів права відноситься конкретний користувач. У той же час при передачі інформації в Їнтернеті конкретний суб'єкт може користуватися засобами захисту інформації (наприклад, електронним цифровим підписом), що дозволяє зробити висновок про його статус, або, наприклад, при розміщенні свого інформаційного ресурсу (сайта) в Їнтернеті його правовий статус можна оцінити за наданою ним інформацією. Наприклад, інформаційні ресурси в Їнтернеті можуть розміщувати громадяни (надаючи інформацію про свої інтереси, хобі, ділову та громадську діяльність і т. д.), організації (надаючи інформацію про свої установчі документи, підприємницьку та громадську діяльність, ділових партнерів, звітність і т. д.), а також органи державної влади. На підставі цього можна зробити висновок про те, що в реаліях сучасного Їнтернету не можна достовірно визначити суб'єкта права, за винятком випадків його прямого волевиявлення або сутності конкретних відносин (наприклад, при використанні електронного цифрового підпису).

Структура мережі Їнтернет дозволяє будь-якому користувачеві не тільки отримувати необхідну йому інформацію або здійснювати транзакції, але і брати участь у створенні нових інформаційних ресурсів в мережі. Грунтуючись на цьому, можна зробити висновок про те, що всі суб'єкти відносин в Іेнтернеті є споживачами інформації з мережі. Виняток можуть становити лише особи або організації, чиї права порушуються в мережі без їх відома.

Наприклад, при незаконному поширенні конфіденційної інформації в мережі або при незаконному поширенні творів суб'єкти, права яких 
порушуються, можуть не знати про те, що відбувається правопорушення, і не бути користувачами Інтернету [35, с. 32].

Розміщення в мережі Їнтернет інформації, доступ до цієї інформації, а також «внутрішньомережевий» обмін інформацією здійснюється за участю спеціалізованих організацій - постачальників послуг Іेнтернету. При цьому сам «Іінтернет» як сукупність інформаційних ресурсів непідконтрольний якійсь конкретній особі, державі або міжнародній організації. Можливості окремих держав, міжнародних організацій або світового співтовариства в цілому впливати на зміни цієї ситуації являють собою надзвичайно цікаву тему, однак безумовно виходить за межі даного дослідження.

Сьогодні можна вести мову про те, що, по-перше, кожен провайдер має можливість контролювати інформацію, яка передається в мережу або виходить з мережі при користуванні його послугами. У цьому сенсі кожен провайдер має потенційну можливість встановлювати певні стандарти користування мережею для своїх клієнтів.

По-друге, держава має можливість регулювати і контролювати діяльність провайдерів, що надають послуги на іiі території, за допомогою різних юридичних інститутів. Рівним чином держава має можливість регулювати і контролювати діяльність будь-яких осіб, які розміщують (передавачі) «Іінтернет» інформацію з іiі території і (або) отримують таку інформацію на її території. По-третє, режим інформаційного обміну 3 використанням мережі «інтернет» може бути предметом міжнародноправового регулювання. Виходячи з розглянутих вище можливостей окремих держав в області регламентації відповідних відносин, з їх врегулюванням на міждержавному рівні не виникає жодних складностей: стандартні механізми міжнародного права тут застосовні рівно настільки, наскільки вони застосовні в будь-якій іншій області.

Таким чином, будь-які відносини, що виникають у зв'язку з використанням мережі Їнтернет, можуть бути предметом правового регулювання, причому як на внутрішньодержавному, так і на міжнародному рівні. Вони не мають якихось властивостей, що виводять їх зі сфери впливу правової норми. В той же час такі відносини безумовно мають специфіку, яка вимагає певної адаптації юридичних інститутів (ця адаптація в тому або іншому ракурсі складає по суті основний предмет будь-якого дослідження у галузі правового регулювання використання мережі «Інтернет»).

Технічне розміщення інформації в мережі Їнтернет і отримання інформації з мережі можуть здійснюватися на анонімній основі. При цьому анонімно може діяти конкретний користувач мережі (тобто клієнта провайдера, який розмістив або отримав певну інформацію, визначити неможливо), проте завжди можна встановити факт поширення інформації певним постачальником або отримання інформації за допомогою послуг певного провайдера. Все сказане повинно бути прийнято 3 певними застереженнями. По-перше, існуюча технологія доступу в Їнтернет (як при розміщенні, так і при отриманні інформації) в принципі повинна 
дозволяти ідентифікувати місце, з якого особа розмістила/отримала інформацію, здійснила доступ в мережу. Під «місцем доступу» слід розуміти фізично виділену лінію зв'язку або індивідуально визначений пристрій зв'язку, до якої (якого) підключено один кінцевий пристрій (комп'ютер). У більшості випадків мова йде про банальну телефонну лінію, підключену до певної квартири (або іншу лінію зв'язку, або визначений мобільний телефон і т.д.). İ це межа. При тому, що принципово не існує можливість достовірно визначити особу - учасника відповідного інформаційного обміну, навіть можливість встановлення місця доступу обмежена «внутрішньомережевими» технологіями, здатними на надзвичайно високому рівні гарантувати анонімність. По-друге, не можна виключати можливості появи спеціальних програмних і технічних засобів, які дозволяли б діяти анонімно також і провайдерам - особливо з огляду на складність організації відносин між ними.

На сьогодні мережа «інтернет» має глобальний масштаб, тобто доступ до мережі можливий з абсолютної більшості країн світу. Якщо виключити ті нечисленні країни, які не володіють необхідними технічними ресурсами для доступу в Їнтернет, а також держави, які заборонили користування мережею виключно на своїх територіях, то ми одержимо таку картину. Будь-яка особа на території будь-якої держави при наявності необхідних технічних і програмних засобів може: отримати інформацію, розміщену в мережі (передану в мережу) з будь-якої держави, при цьому, як уже зазначалось, сам носій інформації фізично може перебувати також у будь-якій державі; передати інформацію в мережу, тобто зробити її доступною для будь-якого користувача мережі, незалежно від того, з якої країни здійснюється доступ. Рівним чином передати інформацію можна адресно, тобто зробити ії доступною для окремого користувача, здійснюючого доступ з певної країни.

3 перших двох тез випливає, що Їнтернет дозволяє здійснювати обмін інформацією між користувачами мережі, що знаходяться в будь-яких державах світу.

Отже, навіть побіжне дослідження проблемних питань, пов'язаних 3 визначенням правової природи самої мережі Їнтернет, об'єктів та суб'єктів відносин, що виникають у цій сфері, дозволяє вести мову про певні особливості цих відносин.

İ тут серед науковців немає одностайності, і питання про правову природу відносин, що виникають, змінюються і припиняються у сфері використання мережі Їнтернет, є найбільш дискусійним і складним.

Аналіз висловлюваних в юридичній доктрині позицій дозволяє зробити висновок, що одні вчені (Ю. Є. Булатецький, А. Б. Венгеров, В. О. Копилов та ін.) виходять із загальної теорії правовідносин і виокремлюють такий вид правовідносин, як інформаційні правовідносини або ще вужчу категорію - правовідносини в Їнтернеті.

Так, на думку В. О. Копилова, однорідність та особливості інформаційних відносин визначаються особливостями і юридичними властивос- 
тями об'єктів, із приводу яких або у зв'язку з якими вони виникають, а саме: інформації та інформаційних об’єктів, інформаційних технологій, засобів їх забезпечення, засобів зв'язку і телекомунікацій. Особливості ж інформаційних відносин зводяться до того, що вони виникають, розвиваються і припиняються в інформаційній сфері при обігу інформації; опосередковують державну політику визнання, дотримання та захисту інформаційних прав і свобод людини і громадянина в інформаційній сфері; відображають особливості застосування публічно-правових та цивільно-правових методів правового регулювання при здійсненні інформаційних прав і свобод з урахуванням специфічних особливостей та юридичних властивостей інформації та інформаційних об'єктів [9, с. 37].

Їнформаційними ці відносини називав ще А. Венгеров і визначав як соціальні відносини, що мають техніко-організаційну сторону і соціальний зміст, які виокремлюються на певному етапі розвитку суспільства (для цілей автоматизації управління); це відносини, котрі складаються у сфері управління господарством між робітниками, їх колективами в процесі реєстрації, збору, передачі, зберігання і обробки інформації. Вони мають об'єктивний характер, тобто оформлюються в об'єктивну матеріальну форму [36].

Їнші ж науковці відходять від традиційних понять теорії права і вводять нове поняття «інтернет-відносини», розуміючи під ним віртуальні відносини, які виникають в мережі Їнтернет та регулюються нормами права та етики.

Наприклад, І̇. М. Рассолов пропонує говорити про інтернет-відносини, які $€$ частиною відносин у віртуальному просторі (включаючи моральні, етичні та інші види відносин), учасники яких виступають як носії суб'єктивних прав та обов'язків в Їнтернеті. Особливостями таких відносин $€$ те, що вони можуть виникати між особливими суб'єктами (наприклад, операторами зв'язку, провайдерами, розробниками мереж, міжнародними організаціями, відповідальними за розвиток протоколів Їнтернету); ці суб'єкти можуть перебувати в різних країнах, їх діяльність може регулюватися законодавствами різних країн; Іेнтернет-відносини неможливі без використання інформаційно-телекомунікаційних технологій і мереж; ці відносини виділяються на певному етапі розвитку суспільства, держави і технологій [10, с. 72-74].

Деякі ж науковці, дотримуючись традиційного підходу до визначення правової природи відносин, які виникають у мережі Їнтернет, виділяють при цьому низку особливостей, притаманних цим правовідносинам. На думку С. В. Малахова, існуючі в Їнтернеті цивільні правовідносини мають характеристики, які відрізняють іх від інших цивільних правовідносин, а саме: наявність нетрадиційної передумови (суб'єктами можуть бути тільки користувачі Їнтернету, що володіють необхідним доступом в мережу); віртуальність (існують тільки при використанні спеціального програмного і технічного (апаратного) забезпечення в штучно створеному і підтримуваному комп'ютерами середовищі); існування у невизначе- 
ному фізичними межами просторі, що може тягти за собою відсутність дієвого механізму правового регулювання [11, с. 14-15].

У літературі також висловлюється точка зору, що Інтернет сам по собі не породжує виникнення правовідносин. Це пояснюється тим, що Іेнтернет як інформаційно-телекомунікаційна мережа не створює нових об’єктів та товарів, а лише надає можливості для їх створення, розміщення та доступу до них користувачів мережі. Відносини ж, які виникають у зв'язку з функціонуванням Їнтернету як інформаційно-телекомунікаційної мережі (маються на увазі технічні апаратні та програмні засоби з'єднання комп'ютерів), належать більше до сфери технічних стандартів та майже не носять правового характеру. У тих небагатьох випадках, коли те чи інше правове регулювання все ж застосовується, його предметом стають послуги, суб'єктивні права та матеріальні об'єкти, які нічим принципово не відрізняються від предметів аналогічного правового регулювання, що існували до появи Іेнтернету [37, с. 18].

3 такою позицією можна погодитися лише в тому, що в цілому мережа Їнтернет, виступаючи об'єктом правового впливу, сама по собі не спричинює виникнення, зміну та припинення правовідносин. Останні виникають із приводу різних елементів складної багаторівневої інфраструктури мережі Інтернет.

Безперечно відносини, які виникають у зв'язку з існуванням та практичним використанням мережі Їнтернет, мають свою специфіку, яка виявляється у суб'єктному складі, об'єктах та змісті цих правовідносин. Слід погодитися з М.Б. Касьоновою в тому, що на кожному з інфраструктурних рівні мережі Їнтернет складаються відповідні правові відносини, в яких беруть участь різні суб'єкти права та які виникають із приводу досить специфічних об'єктів правового регулювання $[17$, с. 139]. Такі відносини у переважній своїй більшості мають інформаційне наповнення, оскільки складаються із приводу розміщуваної в Інтернеті інформації, та можуть регулюватися за допомогою методів приватного та публічного права або поєднання елементів обох цих методів.

При цьому, як і будь-яке правове відношення, відношення, що виникає в мережі Їнтернет, є складною правовою категорією, що включає в себе набір обов'язкових елементів: 1) суб'єктів; 2) об'єкта; 3) змісту. Підстав для виділення у структурі такого правовідношення будь-яких додаткових елементів, на наш погляд, немає. Адже запропоновані у літературі в якості «особливих» елементів так званих «інтернет-відносин» інформація та технічні засоби становлять не що інше, як об'єкт правовідношення.

Залежно від застосованого критерію при проведенні класифікації пропонуємо виділяти такі види правовідносин в мережі Інтернет:

- залежно від об'єкта регулювання:

- відносини, які виникають із приводу формування національної мережевої інфраструктури підключення та приєднання мереж, використання каналів телекомунікації абонентського обладнання; 
- відносини, які виникають із приводу використання адресного простору відповідного сегмента мережі Їнтернет та розподілу IP-адрес;

- відносини, які виникають із приводу створення та адміністрування доменних назв відповідного сегмента мережі Їнтернет;

- відносини, які виникають із приводу підключення обладнання користувачів до мережі Їнтернет;

- відносини, які виникають із приводу надання послуг хостингу, тобто послуг з розміщення інформаційного ресурсу (веб-сайта) в мережі Іेнтернет шляхом виділення та надання провайдером дискового простору на власному сервері;

- відносини, які виникають із приводу створення, розповсюдження та використання інтернет-контенту, а також надання різного роду інформаційних послуг;

- залежно від суб'єктного складу:

- відносини, які виникають між постачальником мережевих послуг (провайдером) і користувачем мережі Їнтернет;

- відносини, які виникають між користувачами Їнтернету;

- відносини, які виникають між провайдерами (операторами) та уповноваженими органами державної влади;

- залежно від економічного змісту:

- майнові відносини, які виникають із приводу матеріальних благ (наприклад, об’єктів фізичної інфраструктури мережі Їнтернет);

- немайнові відносини, які виникають із приводу нематеріальних благ (наприклад, інформації, інформаційних прав і свобод, прав інтелектуальної власності тощо);

- за галузевою приналежністю:

- цивільно-правові;

- адміністративні;

- господарські та ін.

- залежно від присутності «іноземного елемента» у правовідносинах:

- такі, що ускладнені «іноземним елементом» (наприклад, ситуації коли сервер (об’єкт правовідносин) розміщений за кордоном; провайдер (суб'єкт правовідносин) зареєстрований в іноземній країні; незаконне розміщення об'єктів права інтелектуальної власності в мережі Їнтернет, що мало місце на території іноземної держави (юридичний факт);

- правовідносини, які не ускладнені «іноземним елементом» та не виходять за межі юрисдикції однієї держави.

Таким чином, підсумовуючи проведене дослідження, правовідносини в мережі Їнтернет можна визначити як врегульовані нормами міжнародного та національного права суспільні відносини, які виникають із приводу матеріальних та нематеріальних об'єктів, залучених до структури побудови, системи функціонування та інформаційного наповнення мережі Їнтернет.

Специфіка зазначених правовідносин полягає в тому, що для тих чи інших уповноважених суб'єктів виникають права (тобто відкривається 
передбачена правовими нормами, міжнародними договорами, угодами, рішеннями судів, звичаями і забезпечується різними державами можливість діяти певним чином у віртуальному просторі Їнтернету) і разом 3 тим на інших суб'єктів покладаються обов'язки, які передбачають необхідну поведінку, зафіксовану в джерелах інтернет-права і забезпечену доброю волею сторін або державним примусом. Суб'єктний склад відносин, пов'язаних з використанням мережі Їнтернет, доволі часто виявляється складним. Це зумовлено тим, що користувач входить в мережу завдяки діяльності самостійної особи, що надає такі Їнтернетпослуги - провайдера, доменне ім'я також реєструється самостійною третьою особою - реєстратором, до того ж самостійним суб'єктом $€$ й власник самої адреси сайта, який власником самого сайта може не бути.

На думку Н. А. Дмитрика, до особливостей правовідносин у мережі Їнтернет, що мають юридичне значення, можна також віднести [38, с. 149]: невизначеність місця розташування сторін, що обумовлює можливі проблеми з правом, яке необхідно застосувати, а також 3 реальним виконанням обов'язків; складність ідентифікації учасників правовідносин у мережі; залежність відносин між учасниками мережі від відносин з провайдерами Їнтернет-послуг; електронний характер документообігу в мережі, що обумовлює необхідність застосування спеціального програмного та апаратного забезпечення та інші.

До інших специфічних рис цих відносин належать такі: відносини у віртуальному просторі належать до відносин активного типу, тому що обмін інформацією у мережі Їнтернет завжди супроводжується активними діями з боку учасників інформаційного обміну у цій мережі; фіксація юридичних фактів у віртуальному просторі, виникнення яких зумовлює виникнення, припинення або зміну відповідних відносин, у більшості випадків потребує застосування спеціальних технічних засобів і необхідного програмного забезпечення в силу властивостей цього технологічного середовища.

Наостанок зазначимо, що цивільно-правові відносини у мережі Їнтернет також можуть поділятися на види, наприклад, у залежності від мети, яку переслідує іх встановлення, предмета договорів у мережі. Однак це $є$ предметом окремого дослідження.

Характеристика правовідносин, що виникають у мережі Їнтернет, не буде повною без дослідження змісту цих правовідносин, який також вирізняється певними особливостями.

Перш за все, слід зазначити, що суб'єктивне юридичне право і суб'єктивний юридичний обов'язок мають свою структуру [39, с. 574]. Структура суб'єктивного права - це його будова, яка виражається у зв'язку елементів - юридичних можливостей (правомочностей), наданих суб'єкту. Їстотними елементами суб'єктивного права $€$ такі правомочності: правомочність на власні позитивні дії (правовикористання); правомочність на чужі дії (правовиконання); правомочність домагання (правозахист). 
Слід погодитись з висловленою у літературі точкою зору, відповідно до якої суб'єктивне право у віртуальному просторі може виступати у формі: права-поведінки, права-користування, права-вимоги і права-претензії.

Структура суб'єктивного юридичного обов'язку $€$ зворотним боком суб'єктивного юридичного права і складається у свою чергу із трьох елементів: необхідності зобов'язаного суб'єкта здійснювати певні дії (активні обов'язки) або утриматися від них (пасивні обов'язки); необхідності зобов'язаного суб'єкта реагувати на законні вимоги правомочної сторони (наприклад, обов'язок виконувати умови договору); необхідності нести юридичну відповідальність (зазнавати позбавлення прав особистого, майнового чи організаційного характеру) у разі відмови від виконання юридичних обов'язків або несумлінного їх виконання, якщо суперечить вимогам правової норми.

Суб'єктивні права і обов'язки перебувають у тісному взаємозв'язку, $€$ взаємозалежними, обумовленими одні одними. Завдяки їм між їх носіями - суб'єктами виникає зв'язок, який називається правовідносинами.

Головною особливістю правовідносин, що виникають у мережі Їнтернет, є те, що суб'єктивні права в них, передусім, розкриваються через власні дії користувачів мережі Їнтернет, які спричиняють виникнення, припинення чи зміну прав і обов'язків інших учасників Іेнтернету, а не тільки через обов'язки третіх осіб (інформаційних провайдерів і власників Їнтернет-сайтів) [40, с. 14]. При цьому у системі «суб'єктивне право - здійснення суб'єктивного права - суб'єктивний обов'язок виконання обов'язку» всі елементи взаємопов'язані, а механізм здійснення суб'єктивного права не тільки забезпечує здійснення права, але й містить сукупність умов та засобів здійснення суб'єктивних прав. Як справедливо зазначає Н. А. Дмитрик, механізм здійснення суб'єктивного права, а не саме суб'єктивне право, дозволяє зрозуміти реальний обсяг можливостей, що належать тому чи іншому суб'єкту [38, с. 46].

Суб'єктивне право в Їнтернет-просторі можна визначити як гарантовані нормами права вид і міра можливої чи дозволеної поведінки учасника відповідних відносин. В той же час обов'язок $\epsilon$ видом або мірою належної чи необхідної поведінки.

Найбільш загальним поділом способів здійснення прав у мережі Їнтернет $€$ їх поділ на юридичні та фактичні способи здійснення прав. Подібний поділ можливо застосовувати і для виконання обов'язків. При цьому під фактичними способами здійснення суб'єктивного права розуміється дія або система дій уповноваженої особи, що не мають ознак правочинів. Під юридичними способами здійснення суб'єктивного цивільного права розуміють дію або систему дій, що мають ознаки правочинів, чи інші юридично значимі дії. Мова йде як про двосторонні, так і про односторонні правочини. Разом з тим такий розподіл має досить умовний характер, адже багато видів дій не можна однозначно віднести 
до фактичних або юридичних способів здійснення права. Так, на серверах мережі Їнтернет часто розміщуються екземпляри програм для ЕОМ, причому в деяких випадках вказується, що всі бажаючі можуть безкоштовно використовувати дану програму. Якщо особа копіює (скачує) програму і встановлює іï на свій комп'ютер, вона, з одного боку, здійснює фактичні дії (копіює інформацію), з іншого - вчиняє юридичну дію - угоду з правовласником програми, в силу якої у даної особи виникає право використання конкретного примірника програми.

Визначеність способів здійснення прав та виконання обов'язків залежать від виду прав та обов'язків. Для класифікації способів здійснення суб'єктивних прав принциповим $є$ поділ прав на абсолютні і відносні. Ця відмінність базується на відмінності кола зобов'язаних осіб, що протистоять особі, яка володіє правом. Абсолютними вважаються ті права, де уповноваженій особі протистоїть невизначене коло зобов'язаних осіб, а у випадку з відносними правами, коло зобов'язаних осіб $€$ конкретним [41, с. 294]. 3 точки зору способів здійснення прав і виконання обов'язків важливим $€$ те, що в абсолютних правовідносинах уповноваженій особі протистоять лише пасивно зобов'язані особи, в той час як у зобов'язальних правовідносинах на іншій стороні $€$ одна або кілька осіб, на яких може бути покладено обов'язок активного типу. При цьому суб'єктивне право в абсолютних відносинах здійснюється, як правило, «статистичними» способами, особистими діями правомочного суб'єкта, тоді як у відносних правовідносинах суб'єктивне право здійснюється шляхом звернення вимог до зобов'язаної сторони. Способи виконання обов'язків в абсолютних і відносних правовідносинах також різняться. Характерні для абсолютних правовідносин обов'язки пасивного типу виконуються шляхом дотримання встановлених у законі заборон. Обов'язки активного типу можуть існувати тільки у відносних правовідносинах; вони виконуються активними діями зобов'язаного суб'єкта, які розглядаються законом або договором в якості юридичного факту, що тягне виникнення, зміну або припинення правовідносин.

Способи здійснення прав і виконання обов'язків з використанням мережі Їнтернет в цілому такі ж, що і в інших сферах цивільного обороту, з деякою специфікою, яка пов'язана з особливостями застосовуваних технічних засобів. Як і в звичайному цивільному обороті, найпоширенішим юридичним способом здійснення прав і виконання обов'язків $€$ укладення угод, у тому числі багатосторонніх. Фактичні способи здійснення прав і обов'язків найчастіше пов'язані з використанням належних користувачам мережі Їнтернет об'єктів інтелектуальної власності та іншої інформації і полягають в основному в поширенні інформації за допомогою мережі Їнтернет та здійсненні доступу до неї.

Слід вказати на те, що у віртуальному просторі Їнтернету конструкція суб'єктивного права як міра можливої поведінки або як сукупний набір повноважень дещо змінює свій зміст. Правомочність на захист у більшості зобов'язальних правовідносин у віртуальному просторі носить 
чисто декларативний характер. Правомочність на захист порушених прав, обумовлених договором (договір на надання послуг), обмежується лише скасуванням договірних відносин. Вимога використання державнопримусових заходів у випадку порушення суб'єктивного права в даному випадку важко здійснюється. 3 цієї причини інтернет-компанії в своїх «Правилах користування» частіше за все згадують лише про один вид своїх правомочностей - правомочність припинити надання послуг у разі порушення користувачем умов договору. Таким чином, суб'єктивне право суб'єкта цивільних правовідносин в Інтернеті (міра можливої поведінки) складається з двох правомочностей: правомочності на власні дії (самостійного здійснення юридично значимих дій) і правомочності вимоги (можливість вимоги від сторони зобов'язання виконання обов'язків). Правомочність на захист у вигляді реалізації державно-примусових заходів у даному випадку стає декларативною правомочністю, оскільки компанія, що надає інтернет-послуги, вважає достатнім припинення надання послуг конкретному користувачеві, який порушив умови, озвучені компанією. Таким чином, обсяг суб'єктивних прав уповноваженої особи визначається не нормативними актами, а умовами інтернет-компанії, які $є$ вичерпними.

Виходячи із особливої структури відносин у мережі Їнтернет, на сьогодні проблеми з реалізації прав та обов'язків суб'єктів цієї сфери можна розподілити на проблеми розповсюдження інформації (доменне ім'я, способи розповсюдження та ін.), доступу до інформації (способи доступу і статус посередників), проблеми контенту.

Як зазначає С. В. Петровський, однією з проблем, яка виникає при наданні Їнтернет-послуг, $є$ проблема правового регулювання виключних прав на адресу (доменне ім'я), яка ідентифікує інформаційний ресурс у мережі й пов'язує його з правами на товарний знак та фірмову назву. Більш того, «специфіка мережі Їнтернет проявляється в тому, що кожен Іेнтернет-ресурс може відноситись до окремої території виключно за рахунок реєстрації доменного імені в конкретному сегменті мережі» [42, с. 31], а це, у свою чергу, може означати те, що реєстрація веб-сайта за ознакою доменного імені ще не означає фактичне його розташування у певному регіоні $[43$, с. 39], що може бути визначений наперед в його адресі.

До законодавчих прогалин сьогодення в Україні належить відсутність обов'язку особи, яка має намір створити веб-сайт, надати свої персональні дані (як для фізичних, так і для юридичних осіб) для ідентифікації іï як власника цього сайта [44]. Звісно, у мережі вже розроблено низку заходів для ідентифікації таких осіб за допомогою сервісу «whois», що використовується для направлення запитів 3 приводу отримання інформації про реєстрацію доменного імені до фактичного делегування веб-адреси клієнту, але це не вирішує проблему ідентифікації, тому що, як зазначалося раніше, власником доменного імені і власником інформації, розташованій на веб-сайті, можуть виступати різні особи. 
У національному законодавстві, як і в міжнародних договорах, не використовується поняття «Інтернет» як середовище використання творів та об’єктів суміжних прав [45]. Норми вітчизняного законодавства (Цивільний кодекс України, Закон України «Про авторське право і суміжні права») містять більш широкі поняття, що розповсюджуються на цифрові технології, а саме, відтворення, право на розповсюдження серед широкої публіки (доведення до відома, надання доступу). Основні положення полягають у визначенні прав, пов'язаних з використанням творів, виконань, фонограм у цифровій формі, в тому числі в інтерактивних комп'ютерних мережах. Зокрема, відповідно до положень Договорів BOİВ автори, виконавці, виробники фонограм мають виключні права дозволяти відтворення своїх творів, виконань, фонограм у цифровому середовищі, а також «здійснювати доступ» до своїх творів, виконань, фонограм. До виключного права автора, виконавця, виробника фонограм, відеограм, організації мовлення відноситься право дозволяти відтворення, відповідно, твору, виконання, фонограми, відеограми, програми мовлення (ст. ст. 441, 453-455 ЦК України, ст. ст. 15, 39, 40 Закону України «Про авторське право і суміжні права»).

До виключного права автора, виконавця, виробника фонограм також відноситься право надання доступу будь-якій особі до твору, фонограми та зафіксованого виконання з місця та в час, обраних нею (ст. ст. 453, 454 Цивільного кодексу України, ст. ст. 15, 39, 40 Закону). Слід враховувати, що у тому випадку, коли музичні або відеофайли планується продавати через мережу Інтернет, на це також потрібно отримати дозвіл від автора, виконавця, виробника фонограм, відеограм. Таким чином, для правомірного використання об'єктів авторського права і суміжних прав у мережі Іेнтернет необхідно отримати дозвіл від суб'єктів авторського права і суміжних прав.

Автору чи іншому володільцеві авторських прав належить виключне право на економічну експлуатацію твору в будь-який спосіб. Виключність цього права означає, що, за винятком передбачених законодавством випадків, без дозволу особи, якій належать авторські права на твір, жодна особа не може його якимось чином використовувати. Лише автор та (або) його правонаступник мають виключне право вчиняти ряд дій, пов'язаних з використанням твору [46].

Однією з форм використання твору $€$ право на відтворення [47]. Відтворення (копіювання) - це виготовлення одного чи більше примірників (копій) твору в будь-якій матеріальній формі, в тому числі у звуко- і відеозаписі, а також записі у пам'яті комп'ютера. Як наслідок, примірники твору - це результати його відтворення у будь-якій матеріальній формі дещо детальніше пояснює Акт про авторське право США 1976 року [47], а саме: «матеріальні об’єкти, ... в яких твір зафіксовано будь-яким методом, відомим зараз або тим, що буде винайдено пізніше, з якого вони можуть бути сприйняті, відтворені або іншим чином повідомлені, або безпосередньо, або за допомогою машини чи пристрою». 
Закон України «Про авторське право і суміжні права»[46] описує цей процес як «запис для тимчасового чи постійного зберігання в електронній (у тому числі цифровій), оптичній або іншій формі, яку може зчитувати комп'ютер». Щодо даного питання свою точку зору висловив Вищий господарський суд України. Судом у постанові [48] було справедливо зазначено, що «розміщення творів у мережі Їнтернет у вигляді, доступному для публічного споживання, $є$ їх відтворенням в розумінні ... Закону України про авторське право і суміжні права». Для окреслення самого процесу роботи глобальної мережі $€$ надзвичайно важливою позиція Суду щодо «тимчасового чи постійного зберігання».

Адже будь-який користувач Їнтернету, переглядаючи будь-який контент, розміщений в мережі, створює, як мінімум, сім тимчасових копій цього твору: по одній копії в модемах передаючого та приймаючого комп'ютерів, в одному чи кількох проміжних комп'ютерах - маршрутизаторах, у браузері, а також в оперативній пам'яті, у відеодекомпресіонному чіпі та у відеокарті самого приймаючого комп'ютера, притому не враховуючи копіі, що зберігаються на жорсткому диску користувача комп'ютера. Деякі країни світу у своєму законодавстві навіть не згадують про тимчасові електронні копії, такі, наприклад, як Росія, США все частіше приймають рішення про розповсюдження авторсько-правової охорони на копії творів, зафіксованих в оперативній пам'яті комп'ютера. Потрібно звернути увагу на те, що згідно з позицією національних судів, хоча практика по даній категорії справ не надто велика, тимчасова фіксація розміщеного в Їнтернеті твору в оперативній пам'яті комп'ютера визнається актом відтворення, що у поєднанні з повсякчасним та невід'ємним характером тимчасового копіювання в Іेнтернеті призводить до ситуації, коли кожен користувач Їнтернету автоматично стає потенційним порушником авторських прав [49].

Дане питання потребує гострого реагування, як з боку національного законодавця, так і міжнародних організацій. Проте, звісно перші кроки в даному напрямку були зроблені у 1996 році під егідою Всесвітньої організації інтелектуальної власності (ВОїВ): міжнародні угоди - Договір BОİВ про авторське право [50] та Договір BOİВ про виконання і фонограми $[51$, с. 80]. Обидві ці угоди залишають відкритим питання про те, чи $€$ тимчасові копії в Їнтернеті примірниками творів в юридичному сенсі.

Водночас обидва договори значно зміцнюють право авторів та їхніх правонаступників на розповсюдження творів, зачеплене функціонуванням Їнтернету в не меншому ступені, ніж право на відтворення, а також створюють нові права, які раніше володільцям авторських прав за національним законодавством жодної держави-учасниці не надавались.

Відповідно до основ національного законодавства, автори та їх правонаступники мають виключне право на розповсюдження творів шляхом продажу або відчуження в інший спосіб та здачі в найм чи у прокат [46]. 
При аналізі даного положення стає очевидним той факт, що визначення права на розповсюдження залежить від визначення порушення права на відтворення, оскільки першим передбачається передача прав власності на примірник твору. 3 огляду на цю вимогу копії, для того, щоби право на розповсюдження було порушено, право на відтворення має бути порушеним. Виходячи з цієї залежності, в деяких країнах право на розповсюдження включається до права на відтворення та вважається, що Бернською конвенцією передбачено право на розповсюдження через право на відтворення, закріплене ст. 9. Позиція деяких європейських країн щодо даного питання, говорить про те, що право на розповсюдження не повинно застосовуватися в контексті Їнтернету [52]. Узгоджена Заява щодо ст. ст. 6 та 7 Договору ВОЇВ про авторське право обмежує сферу дії права на розповсюдження зафіксованими копіями, «які можуть бути введені до обігу у вигляді матеріальних об’єктів». Згідно з правилами Європейського Союзу стосовно вільного руху товарів та послуг розглядають трансакції, здійснені за допомогою Інтернету, як послуги, тому відповідно країни Європи вважають передачу інформації через Інтернет послугою, а не товаром. Дана політика Європейського Союзу пояснюється застосуванням його державами-членами «принципу вичерпання», аналогу «доктрини першого продажу», сприйнятої авторсько-правовим законодавством США, України та інших країн.

«Вичерпання» $€$ обмеженням права на розповсюдження. Право на розповсюдження вичерпується із введенням до обігу правомірно виготовлених примірників твору самим володільцем авторських прав на твір або кимсь іншим з його дозволу. Їнакше кажучи, з моменту продажу або відчуження іншим чином володільцем авторських прав примірника твору цей примірник може надалі розповсюджуватись без згоди володільця авторських прав на твір та без виплати йому винагороди. Проте сказане не означає, що з першим продажем також вичерпуються права автора та його правонаступників на інші форми економічної експлуатації твору. Реалізація даного принципу стосовно творів, що передаються в мережі Іेнтернет, викликає певні труднощі, адже набувач примірника твору втрачає його після передачі іншій особі. Варто лише володільцю авторських прав на твір розмістити його примірник в І̇нтернеті, як цей примірник може бути переданий користувачам Їнтернету необмежену кількість разів. Це спричинює конфлікт між правом на відтворення та правом на розповсюдження, оскільки в результаті кожної передачі твору створюється його примірник, в той час як оригінал залишається у того, хто здійснює передачу [53, с. 37].

Наступною формою виключних прав автора та (або) його правонаступників $є$ право на публічне виконання та на публічний показ творів. Українським законом публічне виконання розуміється як «подання за згодою суб'єктів авторського права і (або) суміжних прав творів, виконань, фонограм, передач організацій мовлення шляхом декламації, гри, 
співу, танцю та іншим способом як безпосередньо (у живому виконанні), так і за допомогою будь-яких пристроїв і процесів (за винятком передачі в ефір чи по кабелях) у місцях, де присутні чи можуть бути присутніми особи, які не належать до звичайного кола сім’ї або близьких знайомих цієї сім’ї, незалежно від того, чи присутні вони в одному місці і в один і той самий час або в різних місцях і в різний час», а публічний показ - як «будь-яка демонстрація оригіналу або примірника твору, виконання, фонограми, відеограми, передачі організації мовлення за згодою суб'єктів авторського права і (або) суміжних прав безпосередньо або на екрані за допомогою плівки, слайда, телевізійного кадру тощо (за винятком передачі в ефір чи по кабелях) або за допомогою інших пристроїв чи процесів у місцях, де присутні чи можуть бути присутніми особи, які не належать до звичайного кола однієї сім'ї чи близьких знайомих цієї сім'ї особи, яка здійснює показ, незалежно від того, чи присутні вони в одному місці і в один і той самий час або в різних місцях і в різний час» [46].

Відповідно до Американського акта, право на публічне виконання поширюється на літературні, музичні, драматичні та хореографічні твори, пантоміму, кінофільми та інші аудіовізуальні твори, а право на публічний показ - також і на твори образотворчого мистецтва, включаючи окремі кадри кінофільмів та інших аудіовізуальних творів [47]. Також, відповідно до нього, публічне виконання не поширюється на звукові записи, окрім тих, публічне виконання яких здійснюється шляхом цифрової передачі, хоча публічне виконання звукового запису може порушувати право на публічне виконання музичного твору, який зафіксовано у звуковому записі.

Згідно з американським законодавством, право на публічне виконання та право на публічний показ охоплює право на «передачу» творів, а значить, стосується діяльності по розміщенню творів в Їнтернеті. Але, слід відмітити, що у процесі публічного виконання має відбуватися передача виконання твору, а у випадку публічного показу - примірник самого твору. Так, наприклад, передача закодованих цифровим шляхом звуків музичного твору на комп'ютер користувача Їнтернету може порушувати право на публічний показ (як і право на відтворення і право на розповсюдження), але не право на публічне виконання, оскільки на приймаючому комп'ютері не відбувається виконання твору [52].

Згідно з позицією вітчизняного законодавства, «передача в ефір чи по кабелях» неоднозначно трактується і як «публічне виконання», і як «публічний показ». Тому дане питання потребує доопрацювання відповідно з вимогами, які диктує час.

Відповідно до Бернської конвенції та ряду інших міжнародних актів, за авторами та їхніми правонаступниками визнається виключне право на публічне сповіщення творів. ВОЇВ теж висловила свою позицію з даного приводу, в своєму Глосарії вона визначила публічне сповіщення таким чином: «Представлення твору, виконання, фонограми або передачі 
у вигляді, який може бути сприйнятий будь-яким придатним чином особами в широкому розумінні, тобто особами, які не належать до кола знайомих. Це поняття $є$ ширшим за опублікування і також включає, серед іншого, такі форми використання як публічне виконання, сповіщення публіці шляхом передачі по проводах або безпосереднє сповіщення публіці прийому передачі» [54].

В українському законодавстві теж існує правова позиція, що саме потрібно розуміти під публічним сповіщенням, а саме: «Передача за згодою суб'єктів авторського права і (або) суміжних прав в ефір за допомогою радіохвиль (а також лазерних променів, гама-променів тощо), у тому числі з використанням супутників, чи передача на віддаль за допомогою дротів або будь-якого виду наземного чи підземного (підводного) кабелю (провідникового, оптоволоконного та інших видів) творів, виконань, будь-яких звуків і (або) зображень, їх записів у фонограмах і відеограмах, програм організацій мовлення тощо, коли зазначена передача може бути сприйнята необмеженою кількістю осіб у різних місцях, віддаленість яких від місця передачі $є$ такою, що без зазначеної передачі зображення чи звуку не можуть бути сприйняті». Також в українському законодавстві, на відміну від американського, існують такі терміни, як «публічне виконання», «публічний показ»та «публічна демонстрація», які охоплюють всі інші форми оприлюднення твору, не охоплені поняттям «публічне сповіщення (доведення до загального відома)».

У США ж вважається, що право на публічне сповіщення і право на публічний показ $є$ близькими за змістом концепціями [55, с. 61]. У Бернській конвенції право на публічне сповіщення встановлюється лише стосовно певних категорій об'єктів: виконання драматичних, музично-драматичних та музичних творів, передача в ефір та по дротах, кінематографічні переробки і відтворення літературних та художніх творів, декламування літературних творів, а також кінематографічні твори [56].

Цікавим фактом $є$ те, що норми даної Конвенції стосовно публічного сповіщення не розповсюджуються на всі види творів, що передаються Іेнтернетом (наприклад, комп'ютерні програми, твори образотворчого мистецтва, фотографії та ноти не можуть бути ані передані в ефір чи по дротах, ані декламовані).

Наступною категорією прав, що належать автору твору, є немайнові права. Специфіка цифрового середовища та проблеми, що виникають 3 його використанням, змушують деяких вчених говорити про те, що потрібно взагалі відмовитись від концепції немайнових прав щодо розміщених в Їнтернеті творів. Проте на сьогоднішній день цілком очевидно, що визнання немайнових прав та подальше розповсюдження за допомогою Іेнтернету твору із зміненим іменем автора або без його зазначення (якщо твір був підписаний) $є$ протиправним діянням, що тягне за собою притягнення до відповідальності. Відповідно до ст. 438 Цивільного кодексу України [57], автор твору має право на такі види немайнових прав: вимагати зазначення свого імені у зв'язку з використанням твору, 
якщо це практично можливо; забороняти зазначення свого імені у зв'язку з використанням твору; обирати псевдонім у зв'язку з використанням твору; на недоторканність твору. Також в ст. 14 Закону України «Про авторське право і суміжні права» [58] містяться положення про особисті немайнові права автора, а саме: вимагати визнання свого авторства шляхом зазначення належним чином імені автора на творі і його примірниках і за будь-якого публічного використання твору, якщо це практично можливо; забороняти під час публічного використання твору згадування свого імені, якщо він як автор твору бажає залишитися анонімом; вибирати псевдонім, зазначати і вимагати зазначення псевдоніма замість справжнього імені автора на творі і його примірниках і під час будь-якого його публічного використання; вимагати збереження цілісності твору і протидіяти будь-якому перекручуванню, спотворенню або іншій зміні твору або будь-якому іншому посяганню на твір, що може зашкодити честі і репутації автора.

Цікавим $є$ досвід Польщі стосовно питань дотримання немайнових прав автора. Польське законодавство містить положення стосовно безперешкодного права нагляду над користуванням твору. Дана позиція $\epsilon$ досить цікавою для запозичення вітчизняним законодавцем.

У січні 2014 року закінчилось обговорення проекту Закону «Про внесення змін до деяких законодавчих актів щодо захисту авторського права і суміжних прав у мережі Їнтернет», який було представлено на розгляд Державною службою інтелектуальної власності України. У разі прийняття цього проекту передбачалось блокування сайта провайдером, оператором телекомунікацій на підставі заяви особи, яка вважає, що іiі авторське право та/або суміжні права порушені. При цьому законопроект не вимагав від заявника доведення вини власника веб-сайта. Якщо власник сайта не надає свою відповідь протягом двох робочих днів або не вживає протягом цього терміну заходів щодо припинення порушення авторського права та/або суміжних прав заявника, провайдер, оператор телекомунікацій зобов'язаний заблокувати відповідний сайт. Окрім цього, провайдер, оператор телекомунікацій уповноважуються блокувати адреси в мережі Їнтернет, на яких містяться посилання на сайти, контент яких порушує авторські та/або суміжні права особи.

Разом з тим міжнародний досвід свідчить, що рішення про блокування веб-сайтів приймається здебільшого судовими органами (Великобританія, Австрія, Бельгія тощо). Провайдер, оператор телекомунікацій $€$ суб'єктами господарювання, а не органами влади, що уповноважені обмежувати права особи чи позбавляти іiі цих прав у разі порушення нею законодавства України. Враховуючи зазначене, Інститут Медіа Права $з$ приводу запропонованого законопроекту висловив думку, що єдиною підставою для блокування веб-сайта має бути належно аргументоване рішення суду. При цьому тягар доведення правопорушення має нести заявник - особа, яка вважає, що ії авторські та/або суміжні права порушені [59; 60]. 
Варто зазначити, що законодавство України не містить визначення терміна «власник сайта». Правила домену UA, які $€$ частиною договорів, укладених між Адміністратором домену UA та реєстраторами доменних імен, визначають, що особа, яка бажає користуватися та розпоряджатися певним доменним іменем у публічному домені $€$ реєстрантом. Таким чином, незрозуміло, хто саме виступає як власник сайта і несе відповідальність за порушення авторських та/або суміжних прав.

Слід звернути увагу на Проект Закону про внесення змін до деяких законів України щодо посилення відповідальності за вчинені правопорушення у сфері інформаційної безпеки та боротьби з кіберзлочинністю № 2133а від 19 червня 2015 р. [61], що зобов'язує інтернет-провайдерів блокувати доступ до веб-ресурсів, через які здійснюється поширення інформації, що суперечить Закону «Про основи національної безпеки України», на підставі рішення Національної комісії, що здійснює держрегулювання у сфері зв'язку та інформатизації [62].

Таким чином, можна констатувати, що суб'єктивні права та обов'язки учасників Їнтернет-відносин відрізняються динамікою фактичних способів здійснення прав, що у свою чергу потребує відповідного вдосконалення юридичних способів здійснення прав у цифровому середовищі.

Зростання рівня порушень авторських і суміжних прав у мережі Їнтернет визиває занепокоєння, Україна визнана однією з країн з найбільшим рівнем порушень у даній сфері. Для того щоб виявити причини даного стану речей, необхідним вбачається зробити аналіз законодавства України, проаналізувати позитивні та негативні сторони, існуючі прогалини, а також тенденції розвитку.

Законодавче регулювання мережі Їнтернет в Україні знаходиться на дуже низькому рівні, нормативно-правові акти не розкривають поняття «Інтернет», а деякі з них зовсім не містять даного терміна. Проблематика визначення поняття мережі Їнтернет призвела до того, що законодавець, по суті, вирішив зовсім не використовувати даний термін. Також проблемним $€$ питання виявлення суб'єкта правопорушення, оскільки законодавство не дає чіткої відповіді на дане питання, це може бути як користувач, так і володілець сайта. У проекті Закону «Про внесення змін до деяких законодавчих актів України щодо врегулювання питань авторського права і суміжних прав» та в Рекомендаціях Державної служби інтелектуальної власності передбачена відповідальність також і провайдера. Ще одна проблема, яка виникає в момент доказування вчинення правопорушення в мережі Їнтернет, - це складність та неврегульованість процесу надання та фіксації доказів. Отже, ці проблеми та багато інших свідчать про те, що в законодавстві України відсутні норми, які б повно та конкретно регулювали відносини захисту об'єктів авторського права і суміжних прав у мережі Їнтернет.

Основним законом, який регулює відносини авторського права і суміжних прав, є Цивільний кодекс України, який, по суті, оперує лише загальними положеннями та не містить в собі специфічних статей, по- 
в’язаних з мережею Їнтернет. Однак в ньому врегульоване питання про відтворення твору, відповідно до ст. 441 ЦКУ відтворення будь-яким способом та у будь-якій формі $€$ його використанням, по суті дана стаття також включає в себе і відтворення за допомогою мережі Їнтернет.

Закон України «Про авторське право і суміжні права» містить у собі певні необхідні терміни та положення, що стосуються захисту авторських і суміжних прав у мережі Їнтернет: піратство; контрафактний примірник твору; опублікування твору, фонограми, відеограми (яке включає в себе випуск твору також і в електронній формі); плагіат; способи захисту авторського права і суміжних прав. Однак даний закон також не містить специфічних положень, які стосуються мережі Їнтернет.

Потрібно зауважити, що певні положення щодо захисту об'єктів права інтелектуальної власності в мережі Їнтернет роз'яснюються у рамках Пленуму Верховного Суду України «Про застосування судами норм законодавства у справах про захист авторського права і суміжних прав». В Пленумі надано тлумачення розміщенню творів у мережі Їнтернет - це подання творів до загального відома публіки таким чином, що iii представники можуть здійснити доступ до творів з будь-якого місця i у будь-який час за їх власним бажанням, таке розміщення $є$ правомірним лише з дозволу автора чи іншої особи, яка має авторське право.

Вказується на те, що виготовлення одного або більше примірників твору, відеограми, фонограми в будь-якій матеріальній формі, а також їх запис для тимчасового чи постійного зберігання в електронній (у тому числі цифровій), оптичній або іншій формі, яку може зчитувати комп’ютер, якщо у зв'язку з таким розміщенням у мережі Їнтернет порушуються майнові права суб̆єкта авторського права, дає підстави для судового захисту авторського права. Неправомірне зберігання копії комп'ютерної програми в пам'яті електронного засобу (комп'ютера тощо) $є$ порушенням майнового авторського права [63]. İ хоча ці положення не визнаються обов'язковими, але по суті використовуються судами у практиці вирішення спорів. Але не осягнуто ще безліч питань, які потребують негайного роз'яснення та фіксації в законодавстві. Наприклад, Ю. Іे. Юдкін у своїй статті вказує перелік термінів, які необхідно визначити в законодавчому порядку. Це такі базові поняття, як, власне, мережа Їнтернет, доменне ім'я, директорія, файл, провайдер, хостинг-провайдер, власник доменного імені, сайт, статичне й динамічне представлення інформації, цифрова й аналогова форма представлення інформації, гіперпосилання, фрейм, трафік, клік, peer-to-peer, скачування, форум, ньюс-група та ін. Причому зробити це не в розрізнених підзаконних актах, важкодоступних для користувачів мережі, а в єдиному кодифікованому акті. Без цього всі спроби сформувати ефективний захист авторських прав у мережі Їнтернет приречені на провал. Без цього щоразу у суді навіть в очевидній ситуації треба буде пояснювати судді, про що ми говоримо [64, с. 205].

Державною службою інтелектуальної власності були розроблені Рекомендації для І̇нтернет-провайдерів, контент-провайдерів та користу- 
вачів файлообмінних мереж та інших веб-сервісів щодо правомірного використання об'єктів авторського права і суміжних прав у мережі Іेнтернет. В них визначені порушення авторського права і суміжних прав у мережі Їнтернет, діяльність провайдерів щодо надання послуг у мережі Їнтернет, впровадження заходів, спрямованих на дотримання вимог законодавства при користуванні Їнтернет-послугами та запобігання онлайн-піратству, перспективи внесення змін до законодавства України щодо відповідальності провайдерів [65]. В даній рекомендації, зокрема, вказується на необхідність введення відповідальності постачальників Їнтернет-послуг.

В Україні здійснюються певні спроби внесення змін до законодавства. Наприклад, законопроект № 6523 «Про внесення змін до деяких законодавчих актів України щодо врегулювання питань авторського права і суміжних прав» 2010 року. Оцінюючи проект у цілому, юристи називають його досить сирим та незбалансованим. Проект пропонує виключити з поняття «розповсюдження» безоплатне розповсюдження творів на Їнтернет-ресурсах, оскільки під це поняття підпадатиме лише продаж або інше відчуження оригіналу або примірника твору, тоді як, по-перше, примірником твору визнається лише матеріальна копія, а по-друге, під час копіювання файла з твором не відбувається ані відчуження, ані продажу твору. По суті, проект зводить поняття «розповсюдження» лише до обігу матеріальних копій, тоді як Іेнтернет зазвичай оперує електронними файлами без матеріальних носіїв. Також за даним законопроектом у разі виявлення порушення в мережі Їнтернет суб'єкт авторського права і (або) суміжних прав має право звернутися до особи, за допомогою послуг якої порушується авторське право і (або) суміжні права, у тому числі до провайдера/оператора телекомунікацій, котрий забезпечує доступ до мережі Їнтернет або послуги з розміщення інтернет-сайта абонента на обладнанні провайдера, з вимогою сприяти припиненню порушення авторського права і (або) суміжних прав, яка має бути розглянута протягом двох тижнів, а порушення прав має бути припинене. До умисних порушень авторського права, передбачених ст. 176 Кримінального кодексу України, додаються порушення у мережі Іेнтернет. Також запроваджуються норми про можливість стягнення відшкодування в подвійному розмірі збитків, завданих порушенням авторського права (до речі, аналогічна норма вже давно працює в сусідній Росії), можливість нотаріально засвідчувати зображення веб-сторінок для їхнього подальшого використання як доказів чи можливість укладати ліцензійні угоди на програмне забезпечення не лише у письмовій формі, а й шляхом вчинення конклюдентних дій [66].

Також даним законопроектом передбачається обов'язок провайдера/ оператора телекомунікацій, котрий забезпечує доступ до мережі Їнтернет або послуги з розміщення інтернет-сайта абонента на обладнанні провайдера, в разі порушення авторського права і (або) суміжних прав припинити доступ до мережі Їнтернет або припинити надання послуг 
3 розміщення Їнтернет-сайта абонента на обладнанні провайдера. У разі невиконання зазначеного обов'язку вказана особа, за допомогою послуг якої порушується авторське право і (або) суміжні права, несе з порушником авторського права і (або) суміжних прав солідарну відповідальність за порушення авторського права і (або) суміжних прав.

Також пропонується внести зміни в інші нормативно-правові акти, такі як Цивільний кодекс України, Кодекс України про адміністративні правопорушення, Кримінальний кодекс України, Закон України «Про нотаріат», Закон України «Про телекомунікації», Закон України «Про професійних творчих працівників та творчі спілки», Закон України «Про телебачення і радіомовлення», Закон України «Про розповсюдження примірників аудіовізуальних творів, фонограм, відеограм, комп'ютерних програм, баз даних», Закон України «Про гастрольні заходи в Україні».

3 приводу даного законопроекту ведуться дискусії ще з 2010 року, які не вирішені досі, оскільки більшість статей потребує вдосконалення та уточнення. Однак якщо розглядати його як крок до вдосконалення законодавства у сфері захисту прав інтелектуальної власності від піратства, то його можна використовувати як основу для подальшого розвитку.

Як вбачається з аналізу чинного законодавства, при кваліфікації діянь як порушень у мережі Їнтернет постає проблема визначення не лише ознак порушення, його галузевої приналежності, але й встановлення належного суб'єкта такого правопорушення. Зазначене зумовлює необхідність розробки чіткого механізму захисту прав авторів у мережі Їнтернет з встановленням суб'єктів правовідносин, що виникають, специфіки їх об’єкта [67, с. 226].

Відсутність належної законодавчої бази обумовила поширення плагіату, судові справи щодо якого надзвичайно складні, оскільки довести сам факт плагіату непросто. Поширення набули факти незаконного розповсюдження творів у мережі Їнтернет, їх публічне сповіщення у громадських місцях, наукового плагіату, що призводить до появи так званих «фахівців», досягнення яких викликають великий сумнів. Українські науковці висловлюють занепокоєність розповсюдженням плагіату в усіх сферах суспільного життя [68, с. 6-7].

Тому можна констатувати, що законодавство України майже не містить в собі положень, які стосуються регулювання авторського права і суміжних прав в мережі Їнтернет. А ті положення, які існують, не узгоджені між собою та не містять в собі повну інформацію по даному питанню. Необхідно приділити увагу таким питанням: визначенню необхідних термінів, які використовуються при розгляді справ, пов'язаних з мережею Їнтернет; визначенню суб'єкта правопорушення; порядку взаємодії відповідних органів з юридичними особами при виявленні правопорушення (наприклад, з провайдерами); санкції за порушення авторських і суміжних прав в мережі Їнтернет; порядку надання та фіксації доказів; запобіганню порушенням авторських і суміжних прав в мережі Їнтернет тощо. 


\section{Л і т е р а т у р а}

1. Рассолов И. М. Право и Интернет: теоретические проблемы : дис. ... д-ра юрид. наук / И. М. Рассолов. - М., 2008. - 357 с.

2. Глушков А. В. Проблемы правового регулирования интернет-отношений : дис. ... канд. юрид. наук / А. В. Глушков. - СПб., 2007. - 198 с.

3. Бабкин С. А. Интеллектуальная собственность в глобальной компьютерной сети «Интернет»: проблемы гражданско-правового регулирования в России и США (сравнительно-правовой анализ) : дис. ... канд. юрид. наук / С. А. Бабкин. - М., 2004. $210 \mathrm{c}$.

4. Мамон 3. В. Деякі аспекти захисту авторських прав у мережі Їнтернет [Електронний peсурс] / 3.В.Мамон. - Режим доступу: http://www.yurlex.com.ua/print/ua/ company/contact/index.htm.

5. Литвинов Є. П. Правовідносини в Їнтернет-праві / Є. П. Литвинов // Часопис Київського університету права. - 2013. - № 3. - С. 145-149.

6. Проникнення інтернету в Україні : дані установчих досліджень у II кварталі 2015 [Електронний ресурс] // Дослідницький холдинг Factum Group Ukraine. - Режим доступу: http://www.inau.org.ua/analytics_vuq.phtml.

7. Справочник по сетям на базе протокола Й нтернет (IP) и соответствующим темам и вопросам [Електронний ресурс] / Международній союз электросвязи. - Женева, 2005. - Режим доступу: http://www.itu.int/dms_pub/itu-d/opb/hdb/D-HDB-IP-2005PDF-R.pdf.

8. Петровский С. В. Интернет-услуги в российском праве / С. В. Петровский. - М. : Агентство «Изд. сервис», 2003. - 272 с.

9. Копылов В. А. Информационное право: учебник / В. А. Копылов. - 2-е изд., перераб. и доп. - M., 2002. - 512 с.

10. Рассолов И. М. Право и интернет / И. М. Рассолов. - 2-е изд., доп. - М. : Норма, 2009. - 383 с

11. Малахов С. В. Гражданско-правовое регулирование отношений в глобальной компьютерной сети Интернет : автореф. дис. ... канд. юрид. наук : спец. 12.00 .03 «ражданское право; предпринимательское право; семейное право; международное частное право»/ С. В. Малахов. - М., 2001. - 21 с.

12. Гревцов Ю. И. К проблеме правового регулирования / Ю. И. Гревцов // Правоведение. - 1981. - № 1. - С. 48-54.

13. Матузов Н. И. Теория государства и права : учебник / Н. И. Матузов, А. В. Малько. - М.: Юристъ, 2004. - 512 с.

14. Пазюк А. В. К вопросу о необходимости определения термина «Интернет» в международном праве [Електронний ресурс] / A. В. Пазюк. - Режим доступу: http://iirkiev.academia.edu/AndriiPaziuk.

15. Середа М. Ю. Закрепление права на доступ в сеть Интернет в международно-правовых актах и законодательстве зарубежных стран / М. Ю. Середа // Международное публичное и частное право. - 2013. - № 5. - С. 44-47.

16. Якушев М. В. Есть ли альтернатива интернету? [Електронний ресурс] / M. В. Якущев // Информационное общество. - 2014. - Вып. 2. - С. 4-9. - Режим доступу: http://emag.iis.ru/arc/infosoc/emag.nsf/BPA/ b1f18e618bded11744257d630043c651.

17. Касенова М. Б. Влияние технологической инфраструктуры интернета на формирование правового регулирования использования интернета / М. Б. Касенова // Право и государство: теория и практика. - 2014. - № 12. - С. 138-142.

18. Касенова М.Б. 2015: перспективы трансграничного управления интернетом / М. Б. Касенова // Евразийский юридический журнал. - 2013. - № 11. - С. 19-21.

19. Черкасов А. Сайт - сложный объект авторского права (некоторые аспекты проблемы) [Электронный ресурс] / A. Черкасов. - 2003. - Режим доступа: http:// www.comprice.ru/articles/detail.php? ID $=42322$. 
20. О правовой охране компьютерных программ: Директива Совета Европейских Сообществ 91/250/ЕЭС от 14 мая 1991 г. [Электронный ресурс]. - Режим доступа: http://zakon4.rada.gov.ua/laws/show/994_065.

21. Цивільний кодекс України від 16.01.2003 р. // Відомості Верховної Ради. - 2003. - № 40-44. - Ст. 356.

22. Гражданский кодекс Российской Федерации от 18.12.2006 № 230-ФЗ [Электронный ресурс]. - Режим доступа: http://www.consultant.ru/online.

23. Жуванов Д. Какую форму охраны выбрать для компьютерной программы? [Электронный ресурс] / Д. Жуванов, E.Стогний. - Режим доступа: http://www.inventa.ua/content.php?l=17\&p=103.

24. Дмитришин В. С. Набуття та передання прав на комп'ютерні програми: автореф. дис. ... канд. юрид. наук: 12.00 .03 / В. С. Дмитришин. - K., 2008. - 21 с.

25. Середа С. Правовая защита авторства на программные продукты [Электронный pecypc] / C. Середа. - Режим доступа: http://www.russianlaw.net/law/ip/copyright/ a138.

26. Про охорону прав на знаки для товарів та послуг : Закон України від 15 груд. 1993 р. // Відомості Верховної Ради. - 1994. - № 7. - Ст. 36.

27. «Правила домена.UA» [Электронный ресурс]. - Режим доступа: http://www.domenua.com.ua/uapolicy-rus.php.

28. Жуванов Д. Проблема доменных имен в Украине [Электронный ресурс] / Д. Жуванов, Е.Стогний. - Режим доступа: http://www.inventa.ua/ content.php?l=17\&p=104.

29. Щодо питання віднесення веб-сайту до об’ $є$ ктів авторського права (комп’ютерних програм) : лист М-ва юстиції України від 18 груд. 2006 р. № 19-5-537 // Бухгалтер. - 2007. - № 3 .

30. Щодо веб-сайту як об’єкта авторського права: лист Держ. департаменту інтелектуальної власності М-ва освіти і науки України від 22 січ. 2007 р. № 16-14/231 [Електронний ресурс]. - Режим доступу: http://owk.com.ua/index.php/list-ministerstvaosviti-i-nauki-ukrajini-shchodo-veb-sajtu-yak-ob-ekta-avtorskogo-prava.

31. Ульянова Г. А. Объекты права интеллектуальной собственности, которые обеспечивают функционирование сети Интернет: проблемы правовой охраны / Г. А. Ульянова // Проблемы пиратства в Российской Федерации. Особенности Интернетпиратства: материалы Междунар. науч.-практ. конф. - М. : ГОУ ВПО РГАИС, 2011. - С. 93-99.

32. Бачило И. Л. Информационное право: учеб. для вузов / И. Л. Бачило. - М. : Высш. образование, Юрайт-Издат., 2009. - 454 с.

33. Телекоммуникации и право / под ред. Ю. М. Батурина. - М. : Центр «Право и средства массовой информации». - M., 2003. - 133 с. - (Серия «Журналистика и право»; вып. 26).

34. Бабкин С. А. Интеллектуальная собственность в Интернете / С. А. Бабкин. - M. : АО «Центр ЮрИнфоР», 2006. - 512 с.

35. Дашян М. С. Право информационных магистралей (Law of Information Highways). Вопросы правового регулирования в сфере Интернет / M. С. Дашян. - М. : Волтерс Клувер, 2007. - 288 с.

36. Венгеров А. Б. Право и информация в условиях автоматизации управления. Теоретические проблемы : автореф. дис. ... д-ра юрид. наук / А. Б. Венгеров. - M., 1975.

37. Танимов О.В. О правовой природе и возможности правового регулирования отношений в сети Интернет / О. В. Танимов, Я. В. Кудашкин // Информационное право. - 2012. - № 2. - С. 17-21.

38. Дмитрик Н. А. Осуществление субъективных гражданских прав с использованием сети Интернет / Н. А. Дмитрик. - М. : Волтерс Клувер, 2006. - 200 с.

39. Скакун О.Ф. Теория государства и права (энциклопедический курс) : учеб. для вузов / О.Ф. Скакун. - Х. : Эспада, 2005. - 840 с. 
40. Еннан Р. Поняття, ознаки, сутність, специфіка та види відносин у мережі Їнтернет / Pуслан Еннан // Теорія і практика інтелектуальної власності. - 2013. - № 3. C. $10-19$.

41. Грибанов В.П. Ответственность за нарушение гражданских прав и обязанностей // Осуществление и защита гражданских прав / В. П. Грибанов. - М. : Статут, 2001. - C. 285-356.

42. Незнамов А. В. Особенности компетенции по рассмотрению Интернет-споров: национальный и международный аспекты : дис. ... канд. юрид. наук: спец. 12.00 .05 «Гражданский процесс; арбитражный процесс»/ Незнамов Андрей Bладимирович; Урал. гос. юрид. акад. - Екатеринбург, 2010.

43. Кудряшова Е. В. Юрисдикция (суверенитет) государств и налоговый иммунитет в области косвенного налогообложения / E. B. Кудрящова // Финансовое право. 2005. - № 10 . - С. 39.

44. Єфремова К. В. До перспектив правового регулювання інтернет-правовідносин: господарсько-правовий аспект [Електронний ресурс] / K. B. Єфремова // Право та інноваційне суспільство. - 2014. - № 1. - С. 5-11. - Режим доступу: http:// nbuv.gov.ua/j-pdf/pric_2014_1_3.pdf.

45. Рекомендації для Їнтернет-провайдерів, контент-провайдерів та користувачів файлообмінних мереж та інших веб-сервісів щодо правомірного використання об'єктів авторського права і суміжних прав у мережі Їнтернет [Електронний ресурс]. Режим доступу: http://sips.gov.ua/ua/ip.html.

46. Про авторське право і суміжні права: Закон України від 23 груд. 1993 р. // Відомості Верховної Ради України. - 1994. - № 13. - Ст. 64.

47. Copyright Act of 1976, 17 U.S.C. \$102(а) [Електронний ресурс]. — Режим доступу: http://www.copyright.gov/title17/92chap1.html.

48. Про деякі питання практики вирішення спорів, пов'язаних із захистом прав інтелектуальної власності : постанова Пленуму Вищого Господарського Суду України [Електронний ресурс]. - Режим доступу: http://zakon2.rada.gov.ua/laws/show/ v0012600-12.

49. Mark A. Lemley. Dealing with Overlapping Copyrights on the Internet / Mark A. Lemley // 22 U. DAYTON L. REV. 547. - 1997. - P. 555.

50. Договір ВОЇВ про авторське право [Електронний ресурс]. - Режим доступу: http:/ /www.wipo.int/treaties/ru/ip/wct/wct.html.

51. Дроб'язко Р. В. Договори Всесвітньої організації інтелектуальної власності про авторське право та про виконання і фонограми / B. С. Дроб'язко // Право України. - 2008. - № 12 . - C. 80 .

52. Dr. Jens Gaster. Copyright and Related Rights in the Information Society / Dr. Jens Gaster // SOFTIC Symposium 1995; Problems of Intellectual Property Rights in the Context of the Information Networks. - Tokyo, Japan, 1995. - Vol. 225. - P. 235.

53. Пастухов О. М. Авторське право в Їнтернеті : навч. посіб. / О. М. Пастухов. - K. Школа, 2004. - 144 с.

54. Офіційний сайт Всесвітньої організації інтелектуальної власності [Електронний ресурс]. - Електрон. дан. (1 файл). - Режим доступу: http://www.wipo.int/portal/ru.

55. Comments to Joint Hearing on H.R. 2441 and S. 1284 (prepared statement of Dr. Mihaly Ficsor, Assistant Director General of WIPO). - P. 61.

56. Бернская конвенция об охране литературных и художественных произведений. Парижский акт от 24 июля 1971 года, изменённый 2 октября 1979 года [Електронний ресурс]. - Женева: ВОИС, 1990. - Ст.2(4). - Режим доступу: http://www.wipo.int/treaties/ru.

57. Цивільний кодекс України : Закон України від 16 січ. 2003 р. № 435-IV // Відомості Верховної Ради України. - 2003. - № 40-44. - Ст. 356.

58. Про авторське право і суміжні права: Закон України від 23 груд. 1993 р. // Відомості Верховної Ради України. - 1994. - № 13. - Ст. 64. 
59. Позиція Їнституту Медіа Права щодо законопроекту про захист авторських прав в Іेнтернеті [Електронний ресурс]. - Режим доступу: http://medialaw.org.ua/news/ pozytsiya-instytutu-media-prava-shhodo-za.

60. Демченко X. Нововведення у сфері інтелектуальної власності [Електронний ресурс] / Х. Демченко. - Режим доступу: http://www.legalalliance.com.ua/ukr/press/2169; http://www.legalalliance.com.ua/ukr/press/2169/3

61. Про внесення змін до деяких законів України щодо посилення відповідальності за вчинені правопорушення у сфері інформаційної безпеки та боротьби з кіберзлочинністю: законопроект № 2133а від 19 черв. 2015 р. [Електронний ресурс]. - Режим доступу: http://w1.c1.rada.gov.ua/pls/zweb2/webproc4_1?pf3511=55668.

62. Депутати хочуть зобов'язати провайдерів блокувати доступ до незаконних веб-ресурсів на підставі рішення НКРЗЇ [Електронний ресурс]. - Режим доступу: http://ua.interfax.com.ua/news/political/274414.html.

63. Про застосування судами норм законодавства у справах про захист авторського права і суміжних прав : постанова Пленуму Верховного суду України № 5 від 4 черв. 2010 p. [Електронний ресурс]. - Режим доступу: http://zakon2.rada.gov.ua/laws/ show/v0005700-10/page.

64. Юдкін Ю. І̇. Правові проблеми захисту інформації в мережі Їнтернет / Ю. І̇. Юдкін // Вісник Харківської державної академії дизайну і мистецтв. - 2007. - № 6. C. 202-206.

65. Рекомендації для Їнтернет-провайдерів, контент-провайдерів та користувачів файлообмінних мереж та інших веб-сервісів щодо правомірного використання об'єктів авторського права і суміжних прав у мережі Іेнтернет: рекомендації Держ. служби інтелектуальної власності України [Електронний ресурс]. — Режим доступу: http://sips.gov.ua/ua/ip.html.

66. Підлісний Є. Дискусія: Авторський проект [Електронний ресурс] / Є. Підлісний // Український юрист. - 2012. - № 5. - Режим доступу: http://jurist.ua/?article/131.

67. Харитонова О. І̇. Порівняльно-правові дослідження піратства, контрафакції та плагіату за законодавством України та Польщі / O. I. Харитонова // Часопис цивілістики. - 2014. - № 16. - С. 222-226.

68. Орлова А.В. Проблеми захисту авторського права в Україні / A. B. Орлова, Л. В. Перевалова // Вісник Національного технічного університету «ХПї». - 2014. - № 37 (1080). - C. 4-8.

\section{А нот а ція}

Харитонова О.і., Ульянова Г.О., Кирилюк А.В., Симонян Ю.Ю., Бааджи Н. П., Позова Д.Д., Григор'янц Г. І.,, Бурова Л. І., Мартинюк І. В. Проблемні питання визначення правової природи і структури правовідносин інтелектуальної власності, що виникають у мережі Їнтернет. - Стаття.

Сьогодні під впливом науково-технічного прогресу значно розширилось коло суспільних відносин. Виникає така категорія правовідносин, як «правовідносини в мережі Їнтернет». Постає питання правового регулювання таких відносин, суб'єктного складу, змісту та з приводу чого вони виникають. Саме ці питання розкриті в даній статті.

Ключові слова: правовідносини, Всесвітня мережа Іेнтернет, інтелектуальна власність, учасники відносин, правове регулювання, об’єкт правовідносин, суб'єкт правовідносин, зміст правовідносин. 


\section{А н н о т а ци я}

Харитонова Е.И., Ульянова Г.А., Кирилюк А.В., Симонян Ю.Ю. Бааджи Н.Ф., Позова Д.Д., Григорьянци Г.И., Бурова Л.И., Мартынюк И.В. Проблемные вопросы определения правовой природы и структуры правоотношений интеллектуальной собственности, возникающие в сети Интернет. - Статья.

Сегодня под влиянием научно-технического прогресса значительно расширился круг общественных отношений. Возникает такая категория правоотношений, как «правоотношения в сети Интернет». Возникает вопрос правового регулирования таких отношений, субъектного состава, содержания и по поводу чего они возникают. Именно эти вопросы раскрыты в данной статье.

Ключевые слова: правоотношения, Всемирная сеть Интернет, интеллектуальная собственность, участники отношений, правовое регулирование, объект правоотношений, субъект правоотношений, содержание правоотношений.

\section{S u m m a r y}

Kharitonova E., Ulyanova G., Kyrylyuk A., Baadzhy N., Simonyan Yu. Pozova D., Grigoryants G., Burova L., Martynyuk I. Problem questions determine the legal nature of the legal structure and intellectual property arising on the Internet. Article.

Today, under the influence of scientific - technical progress greatly expanded range of public relations. There is a category of legal relations as «relations in the Internet». This raises the question of legal regulation of relations, subject composition, content, and about which they arise. These questions are described in this article.

Keywords: legal relations, global Internet, intellectual property, the participants relations, legal regulation, object relations, the subject of legal relations, legal content. 